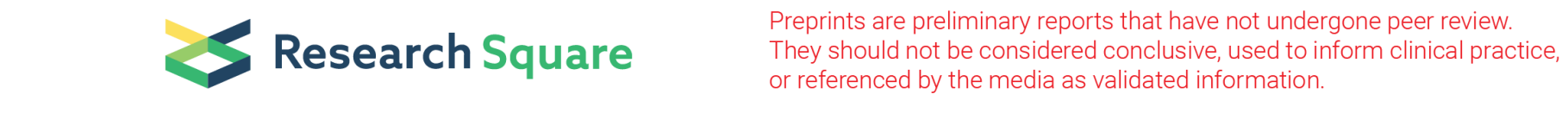

\title{
Effect of Productive Capacities on Economic Complexity: Do Aid for Trade flows Matter?
}

Sèna Kimm GNANGNON ( $\nabla$ kgnangnon@yahoo.fr)

World Trade Organization

\section{Research Article}

Keywords: Productive capacities, Economic complexity, Aid for Trade flows

Posted Date: February 20th, 2021

DOl: https://doi.org/10.21203/rs.3.rs-257879/v1

License: (1) (i) This work is licensed under a Creative Commons Attribution 4.0 International License. Read Full License

Version of Record: A version of this preprint was published at Journal of Economic Integration on December 15th, 2021. See the published version at https://doi.org/10.11130/jei.2021.36.4.626. 


\section{Abstract}

The COVID-19 health pandemic has exposed the strong vulnerabilities of countries, including developing ones to shocks, and underlined the need for exploring ways to strengthen countries' resilience to future shocks. The current paper uses the dataset made recently available by the United Nations Conference on Trade and Development (UNCTAD) to examine (for the first time) the effect of productive capacities on economic complexity. The analysis further investigates whether Aid for Trade (AfT) flows matter for the influence of productive capacities on economic complexity in recipient-countries. The analysis uses a sample of 126 countries (including both developed and developing countries) over the period 2002-2018, and adopts the two-step system Generalized Methods of Moments (GMM) approach. Results have shown that productive capacities exert a positive effect on economic complexity over the full sample. However, the magnitude of this positive effect varies across different sub-samples, with Least developed countries (LDCs) enjoying the lowest magnitude of this positive effect. Furthermore, total AfT flows are positively associated with economic complexity, with LDCs enjoying a higher positive effect than other countries. Interestingly, total AfT flows exert a higher positive effect on economic complexity in countries that experience low levels of overall productive capacities. The latter finding highlights the need for donor-countries to scale-up AfT flows in favour of countries (such as LDCs) that are characterized by low levels of productive capacities. Finally, the empirical outcomes indicate that productive capacities enhance economic complexity in countries that receive higher amounts of total NonAfT flows.

\section{Introduction}

Do productive capacities help to increase economic complexity (i.e., enhance economic sophistication), and do Aid for Trade (AfT) flows matter for the influence of productive capacities on economic complexity? The present paper is essentially an empirical exercise aiming at addressing these two questions. The latter are highly relevant in the current context where the COVID-19 health pandemic has exposed the vulnerabilities of developing economies, and the Least developed countries[1] -LDCs - among them, and underlined the need for national policymakers, international and regional institutions as well as the academic community to explore ways to strengthen productive capacities so as to build economies that are more resilient and immune to future shocks.

The United Nations Conference on Trade and Development (UNCTAD) has been advocating for strengthening productive capacities in developing, and particularly in LDCs with a view to promoting structural transformation of economies, and sustainable growth and development. It has provided a first definition of the concept of "productive capacities" in its report dedicated to LDCs in 2006, which is titled "The Least Developed Countries Report 2006: Developing Productive Capacities" (see UNCTAD, 2006). According to this report (UNCTAD, 2006, p61), productive capacities[2] are "the productive resources, entrepreneurial capabilities and production linkages which together determine the capacity of a country to produce goods and services and enable it to grow and develop". Since 2006, many analytical works (not evidence-based studies) have been undertaken on the issue of "how to foster productive capacities in developing countries", including on challenges faced by developing countries and LDCs in fostering productive capacities, and appropriate policies to address them (e.g., Cornia and Scognamillo, 2016; UNCTAD, 2016, 2020c). Enhancing productive capacities[3] has also been the subject of intense discussions at several international conferences, for example, the fourth United Nations Conference on LDCs in 2011, the second United Nations Conference on Landlocked Developing Countries in 2014, and the fourteenth session of the UNCTAD in 2016. The main missing element in the studies undertaken thus far on the matter of "how to foster productive capacities in developing countries" was the availability of data on productive capacities to help perform relevant data-based analyses. These evidence-based analyses would help identify where challenges related to the development of productive capacities in developing countries lie, and how to address them - including with the support of donors and the international community - so as to ensure that these economies engage on a sustainable economic growth and development path. To facilitate the formulation and implementation of evidenced-based policies related to the issue of productive capacities, the UNCTAD has developed in 2020 an index[4] of productive capacities (covering the period 2000-2008) based on the UNCTAD (2006)'s definition of the concept of 'productive capacities'. The UNCTAD's 2020 report on LDCs titled "The Least Developed Countries Report 2020: Productive Capacities for the New Decade" (see UNCTAD, 2020b) discusses extensively the methodologies used to construct this index, presents its development over time and across countries - for example, for developed countries, developing countries and LDCs (see UNCTAD, 2020b: Chapter 3). It also explores policies that could be implemented by LDCs to develop productive capacities in the new decade (see UNCTAD, 2020b: Chapter 5).

The World Trade Organization (WTO) has also paid a specific attention to the issue of productive capacities in its developing Members. In fact, the preamble of the Marrakesh Agreement establishing the WTO recognizes[5] "the need for positive efforts designed to ensure that developing countries, and especially the least developed among them, secure a share in the growth in international trade commensurate with the needs of their economic development." In that respect, and recognizing challenges faced by developing countries and the LDCs to better integrate in the multilateral trading system, WTO Members launched at the WTO Ministerial Conference held in Hong Kong China in 2005, the AfT Initiative. The genuine purpose of this initiative is to "help developing countries, particularly LDCs build the supply-side capacity and trade-related infrastructure that they need to assist them to implement and benefit from WTO Agreements and more broadly to expand their trade" (see WTO, 2005, Paragraph 57). AfT flows represent the part of the total official development assistance (ODA) flows that are devoted to the promotion of international trade in the recipient-countries. They aim not only to build economic infrastructure[6] (through development of hard and soft infrastructure) but also to strengthen the capacity of the productive sectors to increase production of goods and services that would be competitive in the international market. These aid flows also purport to build the capacity of policymakers in beneficiary-countries (through technical assistance and capacity building activities) to implement trade and trade-related policies that are consistent with WTO rules, and to compensate domestic trading firms for losses incurred in the trade liberalization process.

The current paper is, to the best of our knowledge, the first empirical analysis that uses the index of productive capacities recently developed by the UNCTAD (data on this index and its components was posted on the UNCTAD's statistics portal on 8 February 2021). It investigates the effect of productive capacities (as defined by UNCTAD, 2006, 2020) on economic complexity, as well as whether AfT flows influence this effect. The focus on economic complexity as a potential outcome of fostering productive capacities is dictated by the fact that economic complexity is not only an important driver of current economic growth, but it is also a good predictor of countries' future economic growth and economic development patterns[7]. The concept of 'economic complexity' (also referred to as 'economic sophistication') is relatively new in the literature, and represents the amount of productive knowledge embedded in a country's

Page $2 / 25$ 
productive structure (e.g., Caldarelli et al., 2012; Cristelli et al., 2015; Hausmann et al., 2014; Hausmann and Hidalgo, 2009; Hidalgo et al., 2007; Utkovski et al., 2018). According to Lall et al. (2006), economic complexity is the extent to which countries can produce and export knowledge goods through the knowledge formed in those countries. This concept builds on the idea that a wide range of diverse and exclusive capabilities are needed to produce complex goods, i.e., goods of high value added, that cannot be easily grown by other countries. As defined by Hausmann and Hidalgo (2009), complex economies are those characterised by a wide range of products (i.e., greater export product diversification) that other countries would not be able to produce easily because of the specific capabilities needed to grow these products (i.e., these types of products are qualified as having a low ubiquity). These signify that simpler economies (such as LDCs that mainly export products with low value added, including primary commodities) have a low level of export product diversification, and high ubiquitous products (i.e., products can be easily grown by other countries).

While there is an increasing number of studies[8] looking at the macroeconomic effects of economic complexity, very few works have considered the determinants of economic complexity (e.g., Chu, 2020; Hausmann and Hidalgo, 2014; Lapatinas, 2019; Lapatinas and Litina, 2019; Sepehrdoust et al., 2019). Thus, by investigating the effect of productive capacities on economic complexity, the present paper adds to these few studies on the determinants of economic complexity.

The empirical exercise has been performed over a set of 126 countries (both developed and developing countries) with data spanning the period 2002-2018. It has established several interesting findings. First, fostering productive capacities induces greater economic complexity across the full sample, as well as various sub-samples, with LDCs appearing to enjoy the lowest positive effect of productive capacities on economic complexity. Furthermore, total AfT flows exert a positive effect on economic complexity, including in countries with low levels of productive capacities. Finally, productive capacities exert a higher positive effect on economic complexity in countries that receive higher amounts of NonAfT flows.

The rest of the paper is organized around four sections. Section 2 presents a theoretical discussion on the effect of productive capacities and AfT flows on economic complexity. Section 3 is devoted to the empirical analysis. It lays out the model specification, presents some data analysis, and discusses the econometric approach to estimate this model. Section 4 interprets empirical results, and Section 5 concludes.

[1] Least developed countries are countries qualified by the United Nations as the poorest and most vulnerable ones to external and environment shocks. Information on criteria used to include a country in or graduate it from the category of LDCs could be obtained in the United Nations Office of the High Representative for the Least Developed Countries, Landlocked Developing Countries and Small Island Developing States (OHRLLS) (see online at: https://www.un.org/ohrlls/).

[2] Other definitions of the concept of "productive capacities" have been provided by other international organizations and bodies than the UNCTAD. These organizations have focused on some specific aspects of productive capacities, including for example the industrial, trade or human capacity facets (UNCTAD, 2006: 62-63). For example, another definition of "productive capacities" refers to it as "a set of different types of productive, organizational, technological and innovation capabilities embedded in organizations, institutions and infrastructures whose integration determines the capacity of a country to produce goods and services in a competitive global market" (UNCTAD, 2020a: 29).

[3] The importance of fostering productive capacities for sustainable development in developing countries has been underlined in the 2030 Agenda for Sustainable Development, the Istanbul Programme of Action, the Vienna Programme of Action, the Nairobi Azimio and Nairobi Maafikiano.

[4] Data on the index of productive capacities is available on the UNCTAD's statistics

portal: https://unctadstat.unctad.org/wds/ReportFolders/reportFolders.aspx

[5] See online at: https://www.wto.org/english/docs_e/legal_e/04-wto_e.htm

[6] The hard dimension of infrastructure refers to tangible infrastructure, such as roads, ports, highways, telecommunications, while the soft dimension concerns transparency, customs management, the business environment, and other institutional aspects that are intangible (see Portugal-Perez and Wilson, 2009, 2012).

[7] See for example, Albeaik et al. (2017); Caldarelli et al. (2012); Cristelli et al. (2015); Hausmann et al. (2007); Hausmann and Hidalgo (2009, 2011); Hidalgo et al. (2007); Mealy et al. (2019); Poncet and Starosta de Waldemar (2013a,b); Saviotti and Frenken (2008); Stojkoski et al. (2016) and Zhu and Li (2017). [8] Apart from studies cited above concerning the effect of economic complexity on economic growth and development, other studies on the macroeconomic effects of economic complexity have focused of economic complexity on income inequality (e.g., Hartmann et al., 2017; Le Caous and Huarng, 2020; Lee and Vu, 2020), improve human development (e.g., Le Caous and Huarng, 2020), economic growth volatility (e.g., Güneri and Yalta, 2020; Maggioni et al., 2016; Miranda-Pinto, 2021), economic growth cycles (e.g., Canh and Thanh, 2020), labor share (Arif, 2021), and poverty (Gnangnon, 2021).

\section{Theoretical Framework}

This section discusses how, from a theoretical perspective, both productive capacities (sub-section 2.1) and AfT flows (sub-section 2.2) could influence economic complexity.

\subsection{Effect of productive capacities on economic complexity}

As noted above, the concept of "productive capacities" as defined by the UNCTAD (UNCTAD, 2006; 2020) has three dimensions, including productive resources, entrepreneurial capabilities and production linkages that together determine a country's capacity to produce goods and services and enable it to grow and develop. Productive resources include physical capital (e.g., hard and soft infrastructure; machinery and equipment) and resources accumulation (e.g., human capital accumulated, and natural resources) used by productive firms and farms to expand the range of goods and services produced. Entrepreneurial capabilities encompass skills, knowledge and information available to enterprises to mobilize productive resources so as to transform inputs into outputs (and become competitive or enhance their competitiveness), to invest, innovate, upgrade products and their quality, and even create markets (UNCTAD, 2006: 64). Entrepreneurial capabilities also include entrepreneurship and technological capabilities that shape the complex interaction of individual firm/farm with 
the macroeconomic environment (Lall, 1992, UNCTAD, 2018, 2020b). Production linkages are flows of goods and services, knowledge, technology and information, and productive resources (notably human resources) among productive units (firms/farms). These involve exchanges among firms/farms located in different sectors, and that have different sizes and ownership (UNCTAD, 2020b).

A country's fundamentals shaped by its endowments of physical and human capital, labor, and natural resources, and the quality of its institutions, determine relative costs and patterns of specialization (Hausmann et al., 2007). As noted above, the key feature of a country's level of economic complexity is the 'knowledge' materialized in its productive structure (e.g., Hausmann et al., 2014; Hausmann and Hidalgo, 2009; Hidalgo et al., 2007; Utkovski et al., 2018). At the same time, at the heart of productive capacities is the knowledge endowment of a country that affects its capacity to produce (and export) goods and services. To recall, productive capacities entail here the productive resources (through physical and resource accumulation), the entrepreneurial capabilities (developed through technological learning and innovation) and the production linkages (through backward and forward linkages that arise from greater specialization of firms and farms, and division of labour) that determine the capacity of a country to produce goods and services. According to UNCTAD (Chapter 2, p 31), greater productive capacities make an economy dense and complex. It, therefore, seems natural to think that strengthening productive capacities would induce greater economic complexity, i.e., greater economic sophistication. How can then the strengthening of productive capacities can help promote economic sophistication?

Developing productive resources requires investment in both physical infrastructure and social infrastructure (i.e., human capital, including through education and health). Improving physical infrastructure implies investing for example in energy, transport, and communications (i.e., information, communication and technology - ICT - tools that are the backbone of the digital economy). Physical infrastructure helps to reduce trade costs, and can therefore promote firms' competitiveness in the export markets (e.g., Djankov et al., 2010; Francois and Manchin, 2013; Helble, 2014; Limao and Venables, 2001; Olarreaga, 2016; Portugal-Perez and Wilson, 2012). Similarly, authors such as Olarreaga (2016) and Portugal-Perez and Wilson (2012) have shown that communications infrastructure, including ICTs, help to reduce trade costs and generate higher trade flows. Dennis and Shepherd $(2007,2011)$ and Beverelli et al. $(2015)$ have demonstrated theoretically and empirically that development of infrastructure that facilitate trade encourages export product diversification, including at the extensive margins. Sepehrdoust et al. (2019) have noted the critical role of infrastructure in promoting economic sophistication. Moreover, a number of empirical studies[9] have pointed out that greater access to the ICTs, notably the Internet contributes to enhance trade flows, and promotes both export product diversification (e.g., Visser, 2019) and services export diversification (e.g., Gnangnon, 2020a). Lapatinas (2019) has found empirically that by facilitating the creation of new products and hence the acceleration of productive capacity, greater access to the Internet contributes to greater economic sophistication, i.e., economic complexity. In fact, access to the Internet allows firms to benefit from a wide range of knowledge information (information on clients, suppliers and competitors) as well as ideas (e.g., Arthur, 2007; Paunov and Rollo, 2016). This could allow them to develop new export products (e.g., Krugman, 1979; Grossman and Helpman, 1989), including sophisticated ones, and benefit particularly to firms with small sizes (e.g., Acs et al., 1994). Likewise, facilitation access to the Internet by informal firms allows them to overcome key barriers (e.g., limited resources) that hamper their ability to build knowledge networks and innovate (e.g., Jensen, 2007). These explain why promoting access to the Internet increases the number of innovating firms, and enhances inclusive innovation in emerging and developing countries (e.g., OECD, 2015; Paunov, 2013). In turn, as innovation promotes export product diversification (e.g., Chen, 2013), one can expect that the Internet and more generally, ICT tools could promote export product diversification towards highly sophisticated goods. Moreover, Cirera et al. (2015) have used firm-level data concerning Brazil to show that innovative efforts play a key role in explaining firms' export diversification. From the discussion above, we can expect that physical infrastructure would be positively associated with economic complexity.

The literature has also underlined that human capital development is essential for economic sophistication. As noted above, human capital development contributes to determining the type of goods (and services) that a country can export (e.g., Hausman et al., 2007). This argument is supported by many empirical studies on the macroeconomic determinants of export product diversification (e.g., Agosin et al., 2012; Giri et al., 2019; Gnangnon, 2019, 2020a,b; Gnangnon and Roberts, 2017; Osakwe et al., 2018; Zhu and Fu, 2013). For example, countries endowed with low-skilled workers are likely to export goods and services that are intensive in low-skilled human resources, while countries with highly developed skills could export highly sophisticated goods (and services). As a result, enhancing human capital could encourage the development of new and sophisticated products, and enhance economic complexity. Lapatinas and Litina (2019) have obtained empirical evidence that countries whose populations enjoy a high-intellectual quotient produce and export more complex goods.

In light of the potential positive effect of innovation on economic complexity highlighted (above), and given that knowledge development is at the heart of the complexification of economies, it can be straightforward to argue that improved entrepreneurial capabilities will contribute to greater economic sophistication (e.g., Caldarelli et al. 2012; Cristelli et al., 2013, 2015; Hausmann et al., 2014; Hidalgo and Hausmann, 2009; Hidalgo et al., 2007).

Finally, we expect enhanced production linkages to facilitate the complexification of economies (UNCTAD, 2020 - Chapter 2). Production linkages permit the flows of goods and services, knowledge, technology and information, and productive resources (including human resources) (UNCTAD, 2020). Hence, strengthening production linkages would promote the exchange of ideas, innovation and the development of new products with high value added, which could ultimately result in greater economic complexification. Production linkages requires, inter alia, the development of the private sector, accompanied by sound policies and strong institutions to facilitate exchanges among firms in different sectors.

Overall, we expect the development and strengthening of productive capacities to lead to greater economic complexity. The overall productive capacity index developed by the UNCTAD (see UNCTAD, 2020) contains eight components, which reflect the three dimensions of productive capacities highlighted above, namely productive resources, entrepreneurial capabilities and production linkages. These eight indicators include ICTs, energy, transport, structural change, natural capital endowment, human capital, the private sector, and institutional quality. In light of the discussion presented above, we can expect that all indicators except the natural resources' indicator would be positively associated with economic complexity. The effect of natural resources on economic complexity could depend on whether countries rely on these resources to produce highly sophisticated goods, or whether such resources hinder their ability (for example through the Dutch disease phenomenon) to diversify export products away from low value-added and towards complex goods (e.g., Bahar and Santos, 2018; Djimeu and Omgba, 2019; Ross, 2019). Using the rents extracted by natural resource-dependent countries from domestic sales and export of

Page $4 / 25$ 
natural resources products to expand the range of export products (by producing and exporting products with higher value added) would surely contribute to the sophistication of economies. In a nutshell, we can expect that while dependence on natural resources could influence positively or negatively economic sophistication, the other components of the index of overall productive capacity would likely influence positively economic complexity.

\subsection{Effect of AfT flows on economic complexity}

The literature on the effect of AfT flows has usually used the categorization of AfT flows by the OECD, which distinguishes three main components of total AfT flows. These include AfT flows related to economic infrastructure[10]; AfT flows aiming at fostering productive capacities[11]; and aid dedicated to trade policy and regulations[12]. Therefore, examining the effect of total AfT flows on economic complexity implies considering the effect of each of its three components on economic complexity. The theoretical rationale for the effect of AfT flows on export product diversification is as follows. AfT flows for economic infrastructure (including both soft and hard infrastructure) could contribute to lowering trade costs reduction (e.g., Busse et al., 2012; Cali and TeVelde, 2011; Portugal-Perez and Wilson, 2009; Vijil and Wagner, 2012) and hence, promote the export of complex products. This is because developing infrastructure such as roads, ports, and energy reduces trade costs, and improves trading firms' competitiveness. It could also provide incentives to firms to further invest on research and development as well as other activities aiming at identifying new export products, including increasingly complex ones. Similarly, improving people's access to ICT tools could reduce transaction costs, support knowledge improvement and innovation, and lead to the export of complex products. Therefore, we can expect that higher AfT flows for economic infrastructure could lead to greater economic complexity. AfT for trade policy and regulation helps facilitate the movement of trade flows across borders by improving the border and transport efficiency, through lowering the time, cost, and number of documents required in export and import procedures (e.g., Anderson and Marcouiller, 2002; Busse et al., 2012; Calì and TeVelde, 2011; Helble et al., 2012; Sohn, 2013; Portugal-Perez and Wilson, 2009, 2012; Wilson et al., 2003, 2005). AfT related to trade policy and regulation also helps to build the capacity of recipient-countries' trade policymakers - this takes place through the technical assistance and capacity building activities of the WTO and other organizations involved in trade activities. Policymakers become equipped with trade policy tools that help them both comply with their country's commitments at the WTO, and develop an export strategy conducive to sustainable development. Gnangnon (2018) has found that higher AfT flows for trade policy and regulation are associated with greater trade policy liberalization. As trade policy liberalization can also lead to greater economic complexity (e.g., Sepehrdoust et al. 2019 - see also the discussion below concerning the effect of trade openness on economic complexity), it could ensue that an increase in AfT flows would promote economic complexity.

AfT for building productive capacity targets directly productive sectors, with a view to expanding the range of products and services exported by recipientcountries. This type of AfT flows would result in greater economic sophistication if they were used to encourage the diversification of the export products basket of the recipient-countries toward increasingly high value-added products. However, if AfT for productive capacity was allocated for the production of goods (and services) in which the country has already a competitive advantage, then, it would result in lower economic complexity, as such AfT flows would not help add significant value to the range of products exported by the recipient-country. Overall, we can expect theoretically that higher total AfT flows would be associated with greater economic complexity.

On the empirical front, some recent studies have considered the effect of AfT flows on export product diversification, which is an important aspect of economic complexity. Gnangnon (2019a) has examined the effect of total AfT flows on export product diversification, but has not looked at the effect of the components of total AfT flows on export product diversification. The analysis has revealed that total AfT flows promote export product diversification, including in both LDCs and countries that are not LDCs. Another study undertaken by Kim (2019) has investigated the effect of both total AfT flows and the components of the latter on export product diversification. The author has found that in the short-run, total AfT flows are associated with greater export product diversification, whilst in the long-run, total AfT flows exert no significant effect on export product diversification. Among the components of total AfT flows, only AfT for productive capacity building has appeared to influence positively export product diversification. Interestingly, Kim (2019) has pushed his analysis further by exploring whether AfT flows matter for economic complexity. He has obtained that neither total AfT, nor its components exert a significant effect on economic complexity. Gnangnon (2019b) has investigated the structural policies that matter for the effect of total AfT flows on export product diversification. He has found that total AfT flows promote export product diversification in countries that liberalize trade policies, experience greater openness of the capital account, or enjoy better institutional and governance quality. In contrast, in countries that are financially developed, AfT flows tend to result in greater export product concentration. Another study by Gnangnon (2019c) has considered the effect of total AfT flows on export structure in the recipientcountries, where export structure has been measured not by an index of export product diversification, but rather by different export ratios: the ratio of exports of low-skilled and technology-intensive manufactures to total primary export products (LOW), the ratio of exports of medium-skilled and technology-intensive manufactures to total primary export products (MEDIUM) and the ratio of exports of high-skilled and technology-intensive manufactures to total primary export products $(\mathrm{HIGH})$. Empirical results have shown for the full sample that total AfT inflows are associated with an increase in the ratios "LOW" and "HIGH", but exert no significant effect on the ratio "MEDIUM". In contrast, over LDCs, total AfT flows generate a rise in the ratio "LOW", but result in a fall in the ratios MEDIUM and HIGH.

Above the afore-mentioned theoretical effects of AfT flows on economic complexity, AfT flows can also influence countries' level of economic complexity through their effects on foreign direct investment (FDI) inflows as well as through the real exchange rate channel. As for the FDI inflows channel, some studies have reported a positive effect of AfT flows on FDI that flow to AfT recipients (e.g., Donaubauer et al., 2016; Lee and Ries, 2016; Ly-My and Lee, 2019). On the other hand, as FDI inflows can be an important vehicle of acquisition and transfer of knowledge, they can influence positively economic complexity. FDI inflows can help to enhance economic sophistication through the (backward) linkages from foreign firms to domestic suppliers (e.g., Görg and Greenaway, 2004; Görg and Srobl, 2001; Gorodnichenko et al., 2020; Hu et al., 2021; Javorcik, 2004; Newman et al., 2015; Smeets, 2008). For example, Gorodnichenko et al. (2020) have obtained that FDI flows exert positive spillover effects on product and technology innovation by domestic firms in emerging markets, with these effects occurring essentially for domestic firms that are engaged directly with multinationals, and involved in international trade. Hu et al. (2021) have found that FDI inflows from China have contributed to technological progress in Africa, while for non-Chinese FDI inflows, it was not the case. Interestingly, the authors have uncovered that South-South FDI has strongly contributed to technological progress in the host country. Newman et al. (2015) have demonstrated 
empirically that higher FDI inflows are associated with direct transfers of knowledge/technology between foreign-owned and domestic firms along the supply chain. These generate direct productivity gains through forward linkages for domestic firms to which foreign-owned firms provide inputs. In addition, there are indirect vertical productivity spillovers from FDI inflows in host countries.

Incidentally, Gnangnon (2020c) has provided empirical evidence that AfT flows are associated with the depreciation of the real exchange rate in recipientcountries. As a depreciation of the real exchange rate is likely to be associated with greater export product diversification (e.g., Guzman et al., 2018; Sekkat, 2016; Sekkat and Varoudakis, 2000; Tran et al., 2017), we postulate that an increase in AfT flows could induce greater export product diversification.

All in all, in light of the foregoing, we expect that higher AfT flows can be associated with greater economic complexity, with this effect being eventually higher for LDCs (among AfT recipient-countries) than in other AfT recipient-countries.

[9] These works include for example Abeliansky and Hilbert (2017); Freund and Weinhold (2002); Freund and Weinhold (2004); Gnangnon and lyer (2018); Lin (2015); Osnago and Tan (2016) and Vemuri and Siddiqi (2009).

[10] This category of AfT covers transport and storage, communications, and energy generation and supply.

[11] AfT for productive capacities covers the sectors of banking and financial services, business and other services, agriculture, fishing, industry, mineral resources and mining, and tourism.

[12] This type of AfT flows concerns trade policy and regulations, as well as trade-related adjustment interventions.

\section{Empirical Analysis}

This section first presents the specification of the model that will help carry out the empirical exercise (see sub-section 3.1). Second, it presents an analysis of data concerning the key variables under analysis, namely the index of overall productive capacities, the indicator of economic complexity, and total AfT flows. Third, it discusses the empirical approach to estimate the model as well as all its different variants (see sub-section 3.2).

\subsection{Model Specification}

In contrast with the voluminous work on the macroeconomic determinants of export product diversification, few studies have investigated the macroeconomic determinants of economic complexity (e.g., Chu, 2020; Hausmann and Hidalgo, 2014; Lapatinas, 2019; Lapatinas and Litina, 2019; Sepehrdoust et al., 2019). The baseline model specification presented below draws from these studies, and includes, apart from our main variables of interest - namely the indicators of productive capacities (i.e, overall productive capacities and its components) as well as total AfT flows -, a set of control variables that are deemed to influence the effect of these key variables of interest on economic complexity. These control variables are development aid flows other than AfT flows, referred to as NonAfT flows, and denoted "NonAfTTOT"; the real per capita income ("GDPC") that reflects the economic development level; the level of trade openness ("OPEN"); the indicator of financial development ("FINDEV"); the population size[13] ("POP") (which captures the country's size); and terms of trade ("TERMS").

The baseline model considered takes a dynamic form and is as follows.

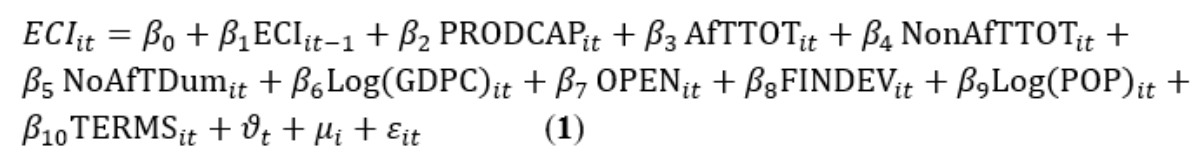

i and t refer respectively to a country and the time-period. The dependent variable "ECl" is the index of economic complexity. The first key regressor of interest "PRODCAP" is the measure of the level of productive capacities, which can be either the overall productive capacities, or each of the eight components of the latter. We denote "PCl" the index of overall productive capacities. Its components include human capital (denoted "HUMCAP"), natural capital (denoted "NATURAL"), energy (denoted "ENERG"), transport (denoted "TRANSP"), ICTs (denoted "ICT"), the private sector (denoted "PRIVATE"), institutions (denoted "INST") and the extent of structural change in output (denoted "SCI"). The variable "AfTTOT" represents the total real gross disbursements of Aid for Trade flows, expressed in constant prices 2018, US Dollar. Following Cali and Te Velde (2011), the dummy variable "NoAfTDum" is introduced in the baseline model specification so as to account for countries that are not recipients of AfT flows. In this way, we are able to include in our full sample, both AfT recipientcountries, as well as countries that are not recipients of AfT flows. Countries that are not recipients of AfT flows include mainly high-income countries (using the countries' classification by the World Bank), of which "old industrialized countries[14]" that we consider as 'developed countries'. Moreover, the inclusion of this dummy variable in the analysis allows examining the effect of productive capacities on economic complexity not over the restricted sample of AfT recipients, but over a larger sample comprising both AfT recipients (that we denote "AfTREC") and high-income countries, in particular our so-called "oldindustrialized countries" (denoted "OLDIND"). The "NoAfTDum" variable takes the value "1" for countries that do not receive AfT flows, and "0", otherwise.

All variables contained in model (1) are described in Appendix 1. The panel dataset used to conduct the empirical exercise covers 126 countries (including AfT recipient-countries and countries that do not receive AfT flows), and the period 2002-2018. The dataset has been averaged over 3-year non-overlapping subperiods, which are 2002-2004, 2005-2007, 2008-2010, 2011-2013, 2014-2016, and 2017-2018 (this last sub-period covers 2 years). to are coefficients needed to be estimated. represent countries' time invariant specific effects. are time-period dummies (i.e., period specific effects) and stand for shocks that affect simultaneously all countries' ability to develop complex economies. is a well-behaving error-term. 
Appendices $2 \mathrm{a}$ and $2 \mathrm{~b}$ report descriptive statistics on all variables used in the analysis (i.e., those contained in the baseline model (1) and those used later in the analysis) respectively over the full sample, as well as over the restricted sample of AfT recipients. Appendices $3 a$ and $3 b$ show the list of countries contained respectively in the full sample and the restricted sample of AfT recipients. Appendix $3 \mathrm{c}$ displays the list of countries contained in the sub-samples of HICs, OLDIND and LDCs.

In terms of the expected theoretical effects of control variables, we expect that a rise in the real per capita income would be positively associated with economic complexity, in particular if the rise in the real per capita income is driven by exports of increasingly sophisticated goods rather than by exports of natural resource products.

NonAfT flows include for example, humanitarian aid and aid allocated for education and health sectors. The literature has shown that higher development aid to the education and health sectors helps to improve education and health in recipient-countries (e.g., Birchler and Michaelowa, 2016; Chauvet et al., 2009; Dreher et al. 2008; Kobayashi et al., 2021; Kotsadam et al. 2018; Lewin, 2020), and hence, enhances human capital, which is essential for ensuring both greater productive capacities and economic complexity. At the same time, Gnangnon (2020c) has shown that NonAfT flows are associated with an appreciation of the real exchange rate (i.e., the relative price of the non-tradables to tradables). An appreciation of the real exchange rate is likely to discourage exports of goods and services (e.g., Eichengreen and Gupta, 2013), notably manufactured exports, and hamper export product diversification (e.g., Guzman et al., 2018; Sekkat, 2016; Sekkat and Varoudakis, 2000; Tran et al., 2017). Consequently, we conjecture that NonAfT flows could discourage the production and export of complex products. Summing-up, the net effect of NonAfT flows on economic complexity could be positive or negative depending on whether the positive effect of these resource inflows on economic complexity through the human capital development channel dominates the eventual negative effect of the resource flows through the real exchange rate channel.

Greater trade openness is expected to influence positively economic complexity by supporting the diffusion of knowledge and transfer of technology, including through the imported goods and services (of which the intermediate goods) at lower costs (e.g., Coe and Helpman 1995;Grossman and Helpman, 1991; Grossman and Helpman 2015; Navas, 2015). Moreover, by through its positive impact on total factor productivity (e.g., Föllmi et al., 2018; Hübler and Pothen, 2017; Melitz 2003; Miller and Upadhyay, 2000), trade openness can induce greater economic sophistication. Sepehrdoust et al. (2019) have reported that trade policy liberalization is conducive to greater economic complexity. However, in their analyses that have used trade openness as a control variable, Lapatinas (2019) and Lapatinas and Litina (2019) have not found a significant effect of trade openness on economic sophistication.

Financial development could help countries export complex products if financial resources allocated by banks to trading firms were used to produce and export high value-added products (e.g., Agosin et al., 2012). However, if those financial resources were invested in the production and export of existing goods and services (that are of low-value added - such as primary commodities) in which the country has a competitive advantage, then financial development would be negatively associated with economic complexity (e.g., Agosin et al., 2012).

Finally, an improvement in terms of trade would generate greater economic complexity if the export revenue derived from such an improvement were invested to encourage innovation and the development of new products with high knowledge content. Otherwise, improvements in terms of trade would result in lower economic sophistication.

\subsection{Data analysis}

This sub-section explores the behaviour of the overall productive capacities, economic complexity, and total AfT flows. We display the developments of productive capacities and economic complexity over the full sample (see Figure 1), over the sub-samples of old industrialized countries (i.e., OLDIND"), HICs and AfTREC (see Figure 2), and over sub-samples of LDCs and the group of "OTHER" countries (i.e., countries among AfT recipients that are not LDCs) (see Figure 3). Figure 4 presents the developments of total AfT inflows as well as that of the share (\%) of total AfT flows in the total gross ODA disbursements flows (both being expressed in constant 2018 prices, \$US) - denoted "SHAfT" - over the restricted sample of AfT recipients, and the sub-samples of LDCs and NonLDCs. Figure 5 depicts the cross plots between the index of overall productive capacity and the indicator of economic complexity over the full sample and the sub-samples "OLDIND", "HICs", "AfTREC", "LDCs" and "OTHER". Finally, Figure 6 shows correlation patterns between total AfT flows and economic complexity over the restricted sample of AfT recipients, as well as sub-samples of "LDCs" and "OTHER".

\section{[Insert Figure 1, here]}

We observe in Figure 1 that over the full sample, productive capacities displayed an upward trend, i.e, they significantly improved over time, from an average of 28.12 in 2002-2004 to 32.26 in 2017-2018. The index of economic complexity increased from -0.018 in 2002-2004 to 0.10 in 2014-2016, and then declined to reach the value 0.005 in 2017-2018. These pictures certainly reflect various developments of these two indices across sub-samples.

\section{[Insert Figure 2, here]}

Figure 2 shows that while the level of economic complexity of old industrialized countries exhibited a downward trend (from 1.3 in $2002-2004$ to 1.17 in 2017 2018), it remained far higher than the average score of economic complexity for HICs taken together (to recall, this group of countries also includes old industrialized countries) and AfT recipients. For both HICs and AfT recipients, the average scores of the economic complexity index slightly improved, from 0.81 in 2002-2004 to 0.92 in 2017-2018 for HICs, and from -0.51 in 2002-2004 to -0.41 in 2017-2018 for AfT recipients. On another note, the average level of productive capacities steadily increased in both old industrialized countries and HICs over the entire period, but it remained slightly higher in old industrialized countries than in HICs. The level of productive capacities for old industrialized countries reached 43.2 in 2017-2018 against 40.2 in 2002-2004. For HICs, it moved from 36.8 in 2002-2004 to 40.7 in 2017-2018. AfT recipient-countries experience a lower level of productive capacities than old industrialized countries and HICs. Notwithstanding this, their average level of productive capacities also improved over time, from 24.3 in 2002-2004 to 28.6 in 2017-2018. 


\section{[Insert Figure 3, here]}

We note from Figure 3 that the index of overall productive capacities was on a steady rise over the entire period for both LDCs and the sub-group "OTHER". The average level of productive capacities in LDCs moved from 19.4 in 2002-2004 to 22.9 in 2017-2018, while for the group "OTHER", it increased from 26.1 in 2002-2004 to 30.7 in 2017-2018. Both LDCs and the NonLDCs among AfT recipients improved their degree of economic complexity over time, although NonLDCs enjoyed a higher level of economic complexity than LDCs. The average level of economic complexity increased from -1.26 in 2002-2004 to -1.02 in 2017-2018 for LDCs, and -0.36 in 2002-2004 to -0.19 in 2017-2018 for the sub-group "OTHER".

A key message conveyed by Figures 2 and 3 is that while the level of economic complexity declined in old industrialized countries, it improved in AfT recipientcountries, and particularly in LDCs among the latter - although this level remained far higher in old industrialized countries than in AfT recipient-countries. At the same time, the level of productive capacities improved in all three sub-samples, although it was higher in old industrialized countries than in AfT recipientcountries (it was also lower in LDCs than in AfT recipient-countries).

\section{[Insert Figure 4, here]}

We observe in Figure 4 that the amounts of total AfT flows consistently increased, on average, over AfT recipients as well as sub-samples of LDCs and "OTHER". Over the full sample, total AfT flows moved upward from \$US million 130 in 2002-2004 to \$US million 363.2 in 2017-2018. For LDCs, total AfT flows amounted \$US million 355.82 in 2002-2004 against \$US million 132.44 in 2002-2004, while for "OTHER", these resources inflows reached \$US million 366 in 2017-2018 against \$US million 129.1 in 2017-2018. These show that the total AfT flows allocated to LDCs yet increased over time, but remained lower than those provided to AfT recipients that are not LDCs, i.e., the sub-group "OTHER". We also note concurrently that the share of total AfT flows in total gross ODA disbursements flows (SHAfT) has increased from 13.8\% in 2002-2004 to $28.25 \%$ in 2017-2018 over the full sample. This trend reflects a rise in this share from $13.07 \%$ in $2002-2004$ to $24.4 \%$ in LDCs, while in the sub-group "OTHER", it increased from $14.1 \%$ in $2002-2004$ to $30.64 \%$ in $2014-2016$, but declined to reach $29.7 \%$ in $2017-2018$.

\section{[Insert Figure 5, here]}

Figure 5 shows positive correlation patterns between the index of economic complexity and the index of overall productive capacities, over the full sample as well as all sub-samples, including "OLDIND", "HICs", "AfTREC", "LDCs" and "OTHER". In other words, productive capacities are positively correlated with economic complexity across all sub-samples.

\section{[Insert Figure 6, here]}

Finally, Figure 6 indicates a slightly positive correlation between total AfT flows and economic complexity in the full sample. A similar pattern is observed for the sub-sample "OTHER", but for LDCs, there is a strong correlation pattern between total AfT flows and economic complexity: the slope of the correlation line is higher for LDCs than for the sub-group "OTHER".

\subsection{Econometric approach and conduct of the empirical exercise}

This section briefly presents the economic approach used to address the issues under analysis, and describes the way the empirical exercise would be conducted.

Relying on previous studies on the determinants of economic complexity (e.g., Chu, 2020; Lapatinas, 2019) and taking cue from previous works concerning the macroeconomic determinants of export product upgrading (e.g., Agosin et al., 2012; Giri et al., 2019; Gnangnon, 2019, 2020a,b; Gnangnon and Roberts, 2017; Osakwe et al., 2018; Zhu and Fu, 2013), we use the well-known two-step system Generalized Methods of Moments (GMM) estimator (see Arellano and Bover, 1995 and Blundell and Bond, 1998) to perform the empirical exercise. This estimator, which is suitable for dynamics panel datasets featured by a large cross-section and a small-time dimension, allows handling endogeneity problems arising from the correlation between the lagged dependent variable and unobserved time invariant individual countries' effects. This estimator also helps to address the endogeneity bias induced by the reverse causality from the dependent variable to the right-hand side regressors. In the present study, this reverse causality can concern the regressors capturing the productive capacities, AfT flows, NonAfT flows, the real per capita income, trade openness and financial development (the variables terms of trade and the population size are considered as exogenous). For example, economic complexity can affect productive capacities because countries whose economies are less complex may be willing to expand their productive capacities so as to export increasingly complex products that would help enhance the resilience of their economies to shocks. Donor-countries may also provide higher amounts of AfT flows and Non-AfT flows to countries that have low levels of economic complexity, with a view to helping them improve their degree of economic sophistication. The degree of economic sophistication can also influence countries' level of trade openness. Likewise, less complex economies may wish to deepen domestic financial markets in order to facilitate the access of their domestic trading firms to banks' credit in order to invest in the production and export of sophisticated goods and services. The two-step system GMM estimator is more efficient than the difference GMM estimator proposed by Arellano and Bond (1991) in the presence of persistent series. This is because with the difference GMM estimator, lagged levels of persistence series are weak instruments for subsequent first difference series. Employing the two-step system GMM approach entails estimating a system of equations that includes an equation in differences and an equation in levels. Lagged first differences are used as instruments for the equation in levels, and lagged levels of variables are used as instruments for the first-difference equation. The consistency of the twostep system GMM estimator relies on the non-rejection of the hypotheses of the presence of first-order serial correlation in the error term (denoted AR(1)), the absence of second-order autocorrelation in the error term (denoted AR(2)), and the Sargan test of over-identifying restrictions of the joint validity of instrumental variables. To ensure that these conditions for the consistency of the two-step system GMM estimator are fulfilled, the regressions described below have used a maximum of 3 lags of the dependent variable as instruments, and 4 lags of endogenous variables as instruments. 
Even though the two-step system GMM estimator is our preferred estimator for the empirical analysis, we start the latter by running regressions of the static specification of model (1) (i.e., without the lagged dependent variable as a right-hand side regressor) by means of the within fixed effects estimator. Table 1 contains the results of these regressions performed over the full sample and the restricted sample "AfTREC". It is likely that these results will be biased because of the endogeneity concerns raised above (in particular the ones arising from the simultaneity bias). However, we have presented the outcomes stemming from the within fixed effects merely to compare those results to the ones obtained when we use the two-step system GMM estimator to estimate the dynamic model (1).

The empirical analysis based on the two-step system GMM estimator is conducted as follows. Estimates reported in Table 2 arise from the estimation (over the full sample) of several specifications of model (1) that include respectively the index of overall productive capacities and each of its eight components (introduced once in the model). These regressions permit, while controlling for the variable representing total AfT flows, to examine not only the effect of the index of overall productive capacities on economic complexity, but also to consider which components of this index influence significantly economic complexity. Results presented in Table 3 are obtained by estimating the same specifications of model (1) but over the restricted sample of AfT recipient-countries.

Column [1] of Table 4 contains outcomes that allow assessing the net effect of productive capacities on economic complexity over the sub-samples of old industrialized countries and LDCs, as well as the net effect of total AfT flows on economic complexity in LDCs versus NonLDCs. To obtain these outcomes, we estimate a specification of model (1) that includes the dummies "LDC" and "OLDIND" (respectively for the sub-samples of old industrialized countries and LDCs). Each of these dummies is interacted with the variable "PCI", which measures the index of overall productive capacities. In addition, the dummy "LDC" is interacted with the variable "AfTTOT" in the same model specification. The dummy "LDC" takes the value "1" for countries categorized as LDCs by the United Nations, and "0", otherwise. The dummy "OLDIND" takes the value " 1 " for countries considered as old industrialized countries, and "0", otherwise. As noted above, the lists of LDCs and old industrialized countries are provided in Appendix 3c. Columns [2] to [9] of Table 4 display the estimates that help to assess the net effect of each component of the index of overall productive capacities on economic complexity, in old industrialized countries and LDCs. To obtain these outcomes, we estimate different other specifications of model (1) in which the relevant component of the index of overall productive capacities is interacted with dummies "LDC" and "OLDIND". Finally, column [10] of the same Table contains estimates that help to obtain the net effect of the overall productive capacities on economic complexity in HICs. These results have the advantage of allowing to check whether the effect of the overall productive capacities on economic complexity in HICs is different from the one obtained over old industrialized countries, insofar as the latter are a sub-set of HICs. The variant of model (1) estimated here is model (1) in which we introduce the dummy "HIC" and its interaction with the index "PCI". The dummy "HIC" takes the value "1" for HICs, and "0", otherwise (see the list of HICs in Appendix 3c).

To perform a robustness check analysis, we run different regressions of some other variants of model (1) yet with the index of overall productive capacities as the measure of "PRODCAP" and total AfT flows, but where the dependent variables are respectively indicators of export product diversification, and the quality of existing export products. These variables represent key aspects of a country's economic complexity. It is noteworthy that we have added the squared term of the real per capita income variable in the model specifications whose dependent variable is the indicator of export product diversification. This is because the literature has well-established a non-linear relationship between the real per capita income and export product diversification (e.g., Cadot et al., 2011; Imbs and Wacziarg, 2003; Parteka and Tamberi, 2013). Measures of export product diversification used here are the UNCTAD's Herfindahl-Hirschman index of export product concentration (denoted "EPCUNCT"), and alternatively the Theil index of export product concentration (denoted "EPCIMF") computed by the International Monetary Fund (IMF). Higher values of both indices indicate greater export product concentration, while lower values reflect greater export product diversification. The index of export quality ("QUALIMF") is also computed by the IMF, with higher values of this index reflecting an improvement in the quality of existing export products. The results of the estimation of all these specifications of model (1) over the full sample and the restricted sample of AfT recipient-countries are presented in Table 5.

Finally, estimates displayed in Table 6 focus on AfT recipient-countries, and allow addressing another key question of the paper, which is whether the effect of productive capacities on economic complexity depends on the amount of AfT flows that accrue to recipient-countries. We also deepen the analysis by investigating whether the effect of the overall productive capacities on economic complexity depends on the amount of NonAfT flows that accrue to recipient-countries. We obtain these outcomes by estimating a specification of model (1) that includes the interaction between the variable representing total AfT flows and the index of overall productive capacities.

[13] Note that we have used the population density variable in replacement with the population size variable (which has been used in the studies on the determinants of export diversification), so as to capture more precisely both the geographic potential of countries and the size of labour (e.g., Chu, 2019; Lapatinas and Litina, 2019). We have obtained that results do not change qualitatively and quantitatively.

[14] We consider as "old industrialized countries" countries that were early members of the Organisation for Economic Co-operation and Development (OECD).

\section{Empirical Results}

In this section, we interpret as significant estimates that are statistically significant at least at the $5 \%$ level.

The estimates reported in Table 1 show that improving the overall productive capacities influences positively and significantly (at the $1 \%$ level) the economic complexity both in the full sample and the sample of AfT recipient-countries. Interestingly, the magnitude of these positive effects are quite similar, and amount to almost 0.3. Similarly, an increase in total AfT flows induces greater economic complexity (the coefficients of the variable "AfTTOT" are positive and significant at the $1 \%$ level, and are without surprise, similar across the two columns of Table 1). NonAfT flows influence negatively and significantly economic complexity. We obtain with regard to other control variables that the real per capita income is positively and significantly associated with economic complexity 
over the full sample, but exerts no significant effect on economic complexity over AfT recipient-countries. Trade openness influences positively and significantly (at the $1 \%$ level) economic complexity over both the full sample and AfT recipient-countries, with the magnitude of this positive effect being similar across the two samples. The coefficient of the financial development indicator is positive and significant at the $1 \%$ level over the full sample, whereas it is only significant at the $10 \%$ level for AfT recipient-countries. Finally, the population size influences significantly economic complexity only at the $10 \%$ level over the full sample, while it exerts no significant effect (at the conventional levels) on economic complexity over AfT recipient-countries. The coefficients of the terms of trade variable are not significant in the two columns of Table 1.

\section{[Insert Table 1, here]}

We now consider the estimates in Tables 2 to 6 . We note form all columns of these Tables that the lagged dependent variable holds coefficients that are positive and significant at the $1 \%$ level. This finding shows the state dependence nature of the indicator of economic complexity, and hence the need for considering a dynamic specification when examining the relationship between productive capacities and economic complexity. All specifications whose results are presented in these five Tables pass[15] the AR(1) and AR(2) tests, as well as the Sargan test on the joint validity of instrumental variables. It is worth noting that the model specification whose results are reported in column [2] of Table 6 passes the Sargan test at the $9 \%$ level (thus, at the 5\% level of statistical significance, the instrumental variables used in this regression are jointly valid). Likewise, the model specification whose results are provided in column [4] of Table 6 passes the AR(2) test at the $7 \%$ level (thus, at the $5 \%$ level of statistical significance, we do not reject the null hypothesis of absence of second order autocorrelation in the error terms). On the basis of these outcomes, we can conclude that the two-step system GMM estimator is acceptable for conducting the empirical analysis.

\section{[Insert Table 2, here]}

Estimates in column [1] of Table 2 show that both the overall productive capacities and total AfT flows are positively and significantly associated with economic complexity. Thus, a 1-point increase in the index of overall productive capacities is associated with a 0.06-point increase in the index of economic complexity. The magnitude of this effect is far lower than the one reported in Table 1. At the same time, doubling total AfT flows (that is an increase in the amount of total AfT flows by $100 \%$ ) results in an increase in the value of the index of economic complexity by 0.02 point. The magnitude of the effect of the overall productive capacities on economic complexity is three times that of the total AfT flows on economic complexity. One important point to note here is that total AfT flows exert a positive and significant effect, across all other columns of Table 2, i.e., when we include each component of the index of overall productive capacities in model (1). This finding runs in contrast to the one obtained by Kim (2019) whereby AfT flows exert no significant effect on economic complexity. It may be noted here that while the model specification considered by Kim (2019) did not contain a measure of productive capacities, the baseline model of this paper does include an indicator capturing countries' level of productive capacities. The coefficients of the components of the index of overall productive capacities reported in columns [2], and [4] to [9] are positive and significant, while the one contained in column [3] is yet significant, but negative. Therefore, we conclude that over the full sample, higher productive resources, including the development of physical infrastructure that enables the provision of energy ("ENERG"), transport ("TRANSP"), and communications ("ICT") induces greater economic sophistication. However, the dependence on natural resources reduces countries' level of economic complexity, and this may confirm our theoretical hypothesis that natural resource dependent countries do not use resources rents to invest in the production of sophisticated products. Furthermore, human capital enhancement, the development of the private sector, and the improvement in institutional quality result in greater economic complexity. Finally, a greater extent of structural change in output induces greater economic complexity.

Total NonAfT flows influence negatively and significantly (at the $1 \%$ level) economic complexity both in column [1], as well as in all other columns of Table 2 . This outcome may suggest that the negative effect of NonAfT flows on economic complexity through the real exchange rate channel likely dominates the potential positive effect of NonAfT flows on economic complexity through the human capital avenue. In terms of the magnitude of the effect of NonAfT flows on economic complexity, we obtain that an increase by $100 \%$ of the amount of total NonAfT flows generates a fall in the value of the index of economic complexity by 0.09 -point. Concerning results related to control variables, we note specifically from column [1] of Table 1 that countries with a lower real per capita income experience a higher level of economic complexity than countries with a higher real per capita income. While this outcome may be surprising, it reflects to a large extent, what we have observed in Figure 2, whereby the level economic complexity in old industrialized countries had been declining while those of AfT recipient-countries and LDCs had been rising. In addition, this outcome may suggest that the effect of the real per capita income on economic complexity may depend on the level of productive capacities, including the components of the latter in recipient-countries. We will check this later when considering results presented in Table 3. Greater trade openness and an increase in the population size influence positively and significantly economic complexity. Financial development does not exert a significant effect on economic complexity, while improvements in terms of trade result in a lower level of economic sophistication. These outcomes of control variables in column [1] of Table 2 are similar, to a large extent, to those in other columns of the Table.

\section{[Insert Table 3, here]}

Results in Table 3 concerning the effect of overall productive capacities (and the components of the latter), AfT flows and NonAfT flows on economic complexity (over the restricted sample of AfT recipient-countries) are fully consistent with those in Table 2, although with different magnitudes of the effect of these variables. We deduce that over AfT recipient-countries, enhancing productive capacities and scaling-up AfT flows contribute to strengthen economic sophistication, which in turn, helps to improve countries' resilience to shocks. A 1-point increase in the index of overall productive capacities induces a rise in the value of the index of economic complexity by 0.086 -point. The magnitude of this positive effect is higher than the one observed in column [1] of Table 2 . For the AfT variable, we obtain that an increase in total AfT flows by $100 \%$ leads to a rise in the value of the index of economic complexity by 0.011 -point. Incidentally, a 100\% increase in total NonAfT flows results in a fall of the degree of economic complexity by 0.095 -point. The positive effect of the overall productive capacities on economic complexity reflects the fact that the latter is positively driven by the supply of physical infrastructure (energy, transport and 
ICT tools), a greater extent of structural change in output, human capital development, the development of the private sector, and an improvement in the institutional quality. However, natural resources dependence reduces the degree of economic complexity.

\section{[Insert Table 4, here]}

We note from Table 4 that the net effect of the overall productive capacities on economic complexity over old-industrialized countries amounts to 0.047 (see column [1] of Table 4). For LDCs, productive capacities exert a lower effect on economic complexity than in other countries in the full sample. This is illustrated by the negative and significant interaction term associated with the interaction variable "PCI*LDC". The magnitude of the net effect of the overall productive capacities on economic complexity in LDCs amounts to $+0.012(=0.0466-0.0351)$. This, therefore, suggests that strengthening productive capacities (in all its dimensions) in LDCs also improves their level of economic sophistication. For countries of the full sample that are neither old industrialized countries, nor LDCs, productive capacities influence positively and significantly economic complexity, with the magnitude of this effect amounting to 0.047 (this is the coefficient of "PCl" in column [1] of Table 4). All these findings show, without surprise, that fostering the overall productive capacities exerts a far higher effect on economic complexity in old industrialized countries than in LDCs. Results also indicate that total AfT flows exert a higher positive effect on economic complexity in LDCs than in other AfT recipients (the coefficient of the interaction term "[Log(AfTTOT)]*LDC" is positive and significant at the $1 \%$ level). The net effect of total AfT flows on economic complexity in LDCs amounts to $+0.127(=0.0260+0.101)$. Turning to the effect of the components of the overall productive capacities on economic complexity (see results across columns [2] to [9] of Table 4), we find for old industrialized countries that at the $5 \%$ level, the net effect of the variables capturing human capital, natural resources dependence, energy, transport, communications, private sector development, institutional quality and extent of structural change amount respectively to $0.35(=0.0217+0.0135) ;-0.00988 ;+0.0366 ; 0 ; 0.025(=$ $0.0103+0.0149) ;+0.036(=0.0152+0.0204) ; 0.00446$; and 0.0611 . These outcomes indicate that in old industrialized countries, economic complexity is positively driven by human capital enhancement, the supply of energy, the access to communications tools, the development of the private sector, the improvement in the institutional quality, and a greater extent of structural change in output. However, the development of transport-related infrastructure does not affect significantly economic complexity in old industrialized countries, while natural resources hinder the sophistication of economies in these countries. At the $5 \%$ level, LDCs experience a higher negative effect of natural resource dependence on economic complexity than other countries in the full sample. Greater access to ICT tools and the set up of better institutions exert a higher positive effect on economic complexity in LDCs than in other countries. However, the effect of structural change in output on economic complexity is lower in LDCs than in other countries. The net effect (at the $5 \%$ level) of the variables capturing human capital, natural resources dependence, energy, transport, communications, private sector development, institutional quality and extent of structural change amount respectively to $0.0217 ;-0.027(=-0.00988-0.0171) ;+0.0366 ;+0.028 ;+0.04(=0.0103+0.0296) ;+0.036(=0.0152+0.0204) ;+0.01$ $(=0.00446+0.00571)$; and $+0.034(=0.0611-0.0275)$. It, therefore, follows that factors that influence positively economic complexity in LDCs are human capital development, greater supply of energy and transport-related infrastructure, a greater access to communications tools, the development of the private sector, the improvement of institutional quality, and a rise in the extent of structural change in output. However, LDCs' dependence in natural resources appears to be an obstacle to their export of sophisticated goods, probably because such dependence results in the Dutch disease effect. This outcome may also signify that LDCs do not use revenue derived from natural resources to diversify their export product basket away from primary commodities.

Finally, we note from column [10] of Table 4 that on average, the effect of the overall productive capacities on economic complexity is lower in HICs than in other countries in the full sample. The net effect of the overall productive capacities on economic complexity in HICs amounts to $+0.036(=0.0603-0.0242)$. To recall, the magnitude of this effect over old industrialized countries amounts to 0.047 . We conclude that while the overall productive capacities drives positively economic complexity in both old industrialized countries (which are a sub-set of HICs) and HICs, the magnitude of this positive effect is higher for old industrialized countries than HICs.

Results in Table 5 allow checking the robustness of previous findings, in particular the ones concerning the effect of the overall productive capacities on economic complexity. We obtain that greater productive capacities influence positively and significantly export product diversification over the full sample as well as the restricted sample of AfT recipient-countries (the coefficient of "PCI" is negative and significant for the regressions based on the UNCTAD's export product concentration index and the IMF's export product concentration index - see columns [1], [2], [4] and [5] of Table 5). Fostering productive capacities also helps to improve export product quality for the full sample and the sample of AfT recipient-countries (see results in columns [3] and [6] of Table 5 that are significant) (the magnitude of this positive effect is higher for AfT recipient-countries than for the full sample).

\section{[Insert Table 5, here]}

Total AfT flows are robustly and positively associated with export product diversification over the full sample and the AfT recipients. However, while these capital inflows contribute to the improvement of the quality of existing export products over the full sample, they exert no significant effect (at the conventional levels) on export product quality over AfT recipient-countries. While over the full sample, NonAfT flows exert no significant effect on export product diversification and export product quality, findings are quite different for AfT recipient-countries. For the latter, NonAfT flows induce greater export product concentration (see columns [4] and [5] of Table 5), but do not affect export product quality.

\section{[Insert Table 6, here]}

Let us now take up results in Table 6. We are interested here in whether the effect of the overall productive capacities on economic complexity in AfT recipientcountries depends on the amounts of total AfT flows that these countries enjoy. The outcomes presented in Table 6 show negative and significant coefficients (at the $1 \%$ level) of both the variable "PCl" and the interaction variable "(PCI*[Log(AfTTOT)])". One interpretation of these outcomes is that the overall productive capacities influence positively economic complexity in countries that receive lower amounts of total AfT flows. Another interpretation of the same outcomes is that total AfT flows influence positively economic complexity in countries with low levels of productive capacities, and the lower these levels, the greater the magnitude of the positive effect of total AfT flows on economic complexity. This means that by strengthening productive capacities in countries that have low levels of overall productive capacities, total AfT flows contribute to enhancing economic sophistication in these countries. We deepen our 
understanding of the interaction between the index of overall productive capacities and the variable measuring total AfT flows by presenting in Figure 7 the development of the marginal effect of the overall productive capacities on economic complexity for varying amounts of total AfT. Alternatively, Figure 8 depicts the development of the marginal effect of total AfT flows on economic complexity for varying levels of the overall productive capacities. Note that the statistically significant marginal impacts (at the 95 per cent confidence intervals) are determined by the upper and lower bounds of the confidence interval that are either above or below the zero line.

\section{[Insert Figure 7, here]}

We observe in Figure 7 that the marginal impact of the overall productive capacities on economic complexity is always positive, but decreases as the amount of the total AfT rises. This signifies that while productive capacities always exert a positive effect on economic complexity (regardless of the amount of total AfT ), countries that receive lower (higher) amounts of total AfT flows are those that experience the highest (lowest) magnitude of the positive effect of productive capacities on economic complexity. This finding may be interpreted by the fact that AfT flows are provided (by donors) to countries that experience low levels of productive capacities, with a view to helping them develop their productive capacities and eventually enhance the complexity of their economies. The validity of this argument needs, however, to be tested in another research paper. The graph in Figure 8 tends to confirm this interpretation of Figure 7. It shows that the marginal impact of total AfT flows on economic complexity can take positive and negative values, but is statistically significant only for positive values. Thus, total AfT flows influence positively economic complexity in countries that experience low levels of (overall) productive capacities, in particular when these levels are lower than 28.5 (this number is obtained from the Stata software when constructing Figure 8). It is also worth noting that values of "PCl" range between 13.9 and 51 (see Appendix 2a). Countries whose levels of productive capacities are higher than 28.5 experience no significant effect of total AfT flows on economic complexity. For the other countries (i.e., whose levels of the overall productive capacities are lower than 28.5), total AfT flows always influence positively economic complexity, but the magnitude of this effect decreases as the level of productive capacities increases: for these countries, the lower the level of productive capacities, the higher is the magnitude of the positive effect of total AfT flows on economic complexity.

\section{[Insert Figure 8, here]}

We go on to examine how NonAfT flows interact with the overall productive capacities in influencing economic complexity. We obtain in Table 6 that the interaction term of the variable "(PCI* $\log ($ NonAfTTOT $)]$ )" is positive and significant at the $1 \%$ level), whereas as noted above, the coefficient of "PCI" is negative and significant at the $1 \%$ level. Taken jointly, these two outcomes suggest that the effect of the overall productive capacities on economic complexity becomes positive (otherwise this effect is negative) when total NonAfT flows exceed a certain amount, given by $\$$ US $6310.7=[$ exponential $(0.0910 / 0.0104)]$. It appears that over the sample of AfT recipient-countries, the minimum amount of total NonAfT flows is \$US million 11.0, while the maximum value of total NonAfT flows is $\$$ US million 12,500 (see Appendix 2b). As the threshold of total NonAfT variable found above (i.e., $\$$ US 6310.7) is far lower than the minimum value of total NonAfT flows, we conclude that regardless of the amount of NonAfT that accrues to countries, the latter always enjoy a positive and significant effect of overall productive capacities on economic complexity. Furthermore, the magnitude of this positive effect increases as the amount of NonAfT flows rises: the greater the amount of NonAfT flows, the higher is the magnitude of the positive effect of overall productive capacities on economic sophistication.

\section{[Insert Figure 9, here]}

Figure 9 presents a better picture on this effect, notably by showing how the marginal effect of the overall productive capacities on economic complexity evolves for varying amounts of total NonAfT. The Figure suggests that this marginal impact is always positive, and increases as the amount of total NonAfT flows rises. This confirms our previous finding that regardless of the amount of total NonAfT flows, the overall productive capacities influence positively economic complexity, and that the size of this positive effect increases as the amount of total NonAfT flows rises. These findings suggest that the negative effect of NonAfT flows on economic complexity found across Tables 2 to 6 hides the fact the genuine effect of NonAfT flows on economic sophistication depends on the level of overall productive capacities in the recipient-countries.

Estimates related to control variables across Tables 3 to 6 line-up with those reported in Table 2.

[15] The consistency of the two-step system GMM estimator rests on p-values related to the AR(1) test being lower than 0.10 (at the $10 \%$ level), p-values associated with the AR(2) test being higher than 0.10 (at the $10 \%$ level), and the Sargan test statistics should be higher than $10 \%$ (at the $10 \%$ level).

\section{Conclusion}

The COVID-19 health pandemic has highlighted the vulnerabilities of countries - including developing ones - to shocks, and therefore, the need for policymakers to adopt measures and policies aiming at enhancing the resilience of their economies to future shocks. Strengthening productive capacities has been argued by the UNCTAD (see for example, UNCTAD, 2006, 2020) as a means to make economies more resilient and immune to future shocks. Thus far, the works carried out on the productive capacities related challenges encountered by developing countries (in particular by LDCs among them), and the policies needed to overcome these challenges, have been essentially analytical, and not been evidence-based. On 8 February 2021, the UNCTAD made available publicly the indicator of productive capacities that it had developed, with a view to helping the research community to perform evidence-based analyses on issues related to productive capacities, and providing policymakers with appropriate recommendations on ways to foster productive capacities.

The present paper makes use of this UNCTAD's dataset on productive capacities to examine empirically the effect of productive capacities on economic complexity. It additionally assesses whether this effect depends on the amount of AfT flows received by developing countries. The rationale for this analysis lies on the fact that complex economies (i.e., those that export complex products) exhibit strong resilience to shocks because they enjoy strong current and future economic growth, as well as lower output volatility, and lower economic growth cycles. 
The analysis has been carried out using a full sample of 126 countries (comprising both developed and developing countries) over the period 2002-2018. It has established interesting findings. First, the strengthening of productive capacities is positively associated with economic complexity over the full sample. However, different results' patterns are observed across sub-samples. As a whole, AfT recipient-countries enjoy a higher positive effect (the effect is almost the double) of the overall productive capacities on economic complexity than old industrialized countries (considered here as developed countries). However, on average, old industrialized countries (which are a sub-set of HICs) experience a higher positive effect of the overall productive capacities on economic complexity than HICs do. Furthermore, LDCs experience yet a positive effect of the overall productive capacities on economic complexity, but the magnitude of this effect is far below those of old industrialized countries, and more generally, HICs. Second, total AfT flows exerts a positive effect on economic complexity over the sample of AfT recipient-countries, and the magnitude of this positive effect is higher for LDCs than for other AfT recipients that are not LDCs. At the same time, NonAfT flows influence negatively economic complexity over the sample of AfT recipient-countries. Third, over the latter, there is a substitutability between the effects of the overall productive capacities and the total AfT flows on economic complexity: While regardless of the amount of total AfT, the effect of productive capacities on economic complexity is always positive, the magnitude of this positive effect decreases as the amount of total AfT rises. Alternatively, total AfT flows exert a positive effect on economic sophistication in countries with low levels of productive capacities, and the magnitude of this positive effect rises for countries with low levels of the overall productive capacities. In the meantime, total AfT flows exert no significant effect on economic complexity in countries with high levels of productive capacities. Taken together, these findings may suggest that AfT flows are effective in enhancing economic complexity in countries that have low levels of productive capacities. This finding calls for exploring in another research paper, whether donorcountries really supply higher amounts of AfT flows to countries that experience low levels of productive capacities. Fourth, the analysis has revealed that the overall productive capacities generate greater economic sophistication in countries that receive higher amounts of total NonAfT, and the magnitude of this positive effect rises as the volume of total NonAfT flows rises. In light of this specific finding, we conclude that the above-mentioned negative effect of NonAfT flows on economic complexity hides the fact that this effect is indeed dependent on recipient-countries' level of overall productive capacities.

Thie findings from this empirical analysis has several policy implications. First, strengthening productive capacities in developing countries helps to complexify these countries' economies, and hence, make them more resilient to future shocks, be the latter external health, economic, financial, or eventually environmental shocks. Second, supplying greater amounts of both AfT flows (and also NonAfT flows) to developing countries with low levels of productive capacity (such as LDCs) would genuinely help them enhance their productive capacities, and consequently improve the capacity of their economies to withstand future shocks, while also engaging in a sustainable development path.

The availability of data on productive capacities can now help identify with accuracy the challenges faced by developing countries and LDCs when they endeavour to develop their productive capacities. The identification of these challenges can, in turn, help consider relevant policies and measures tailored to each country's circumstances to foster productive capacities. Development aid, including both AfT flows and NonAfT flows can be instrumental in achieving this objective in developing countries, notably in those (i.e., LDCs) that need these resources flows the most.

\section{References}

Abeliansky, A. L., and Hilbert, M. (2017). Digital technology and international trade: Is it the quantity of subscriptions or the quality of data speed that matters? Telecommunications Policy, 41(1), 35-48.

Acs, Z. J., Audretsch, D. B., and Feldman, M. P. (1994). R\&D spillovers and recipient firm size. The Review of Economics and Statistics, 76(2), 336-40.

Agosin, M.R., Alvarez, R., and Bravo-Ortega, C. (2012). Determinants of export diversification around the world: 1962-2000. The World Economy, 35 (3), 295315 .

Albeaik, S., Kaltenberg, M., Alsaleh, M., and Hidalgo, C.A. (2017). Measuring the knowledge intensity of economies with an improved measure of economic complexity. arXiv preprint arXiv:1707.05826

Anderson, J. E., Marcouiller, D. (2002). Insecurity and the pattern of trade: an empirical investigation. Review of Economics and Statistics, 84(2), 342-52.

Arellano, M., and Bond, S. (1991). Some Tests of Specification for Panel Data: Monte Carlo Evidence and an Application to Employment Equations. Review of Economic Studies, 58, 277-297.

Arif, I. (2021). Productive knowledge, economic sophistication, and labor share. World Development, 139, 105303.

Arthur, W. B. (2007). The structure of invention. Research Policy, 36(2), 274-287.

Bahar, D., and Santos, M. A. (2018). One more resource curse: Dutch disease and export concentration. Journal of Development Economic, $132,102-114$.

Beverelli, C., Neumueller, S., and The, R. (2015). Export Diversification Effects of the WTO Trade Facilitation Agreement. World Development, 76, $293-310$.

Birchler, K., and Michaelowa, K. (2016). Making aid work for education in developing countries: an analysis of aid effectiveness for primary education coverage and quality. International Journal of Educational Development, 48, 37-52.

Busse, M., Hoekstra, R. and Königer, J. (2012). The impact of aid for trade facilitation on the costs of trading. Kyklos, 65(2), 143-163.

Cadot, O., Carrere, C., and Strauss-Kahn, V. (2011). Export Diversification: What's Behind the Hump? Review of Economics and Statistic, 93, 590-605. 
Caldarelli, G., Cristelli, M., Gabrielli, A., Pietronero, L., Scala, A., Tacchella, A., 2012. A network analysis of countries' export flows: firm grounds for the building blocks of the economy. PLoS One 7 (10), e47278.

Calì, M. \& TeVelde, D. (2011). Does Aid for Trade Really Improve Trade Performance? World Development, 39(5), 725-740.

Canh, N. P., and Thanh, S.D. (2020). The Dynamics of Export Diversification, Economic Complexity and Economic Growth Cycles: Global Evidence. Foreign Trade Review, https://doi.org/10.1177/0015732520970441

Chauvet, L., Gubert, F., Mesplé-Somps, S. (2009). Les transferts des migrants sont-ils plus efficaces que l'aide pour améliorer la santé des enfants? Une évaluation économétrique sur les données inter et intra pays. Revue d’Economie du Développement, 17(4), 41-80.

Chen, W.-C. (2013). The Extensive and Intensive Margins of Exports: The Role of Innovation. The World Economy, 36(5), 607-635.

Chu, L. K. (2019). The effects of financial development on economic sophistication: evidence from panel data. Applied Economics Letters, 27(15), 1260-1263.

Cirera, X., Marin, A., and Markwald, R. (2015). Explaining export diversification through firm innovation decisions: The case of Brazil. Research Policy, 44(10), 1962-1973.

Coe, D.T., and Helpman, E. (1995). International R and D spillovers. European Economic Review 39, 859-87.

Cornia, G.A. and Scognamillo, A. (2016). Clusters of Least Developed Countries, their evolution between 1993 and 2013, and policies to expand their productive capacity. CDP Background Paper No. 33, ST/ESA/2016/CDP/33. United Nations Department of Economic and Social Affairs UN Secretariat, New York.

Cristelli, M., Tacchella, A., Pietronero, L., 2015. The heterogeneous dynamics of economic complexity. PLoS One 10 (2), e0117174.

Dennis, A., and Shepherd, B. (2007). Trade Costs, Barriers to Entry, and Export Diversification in Developing Countries. Policy Research Working Paper; No. 4368. World Bank, Washington, DC.

Dennis, A., and Shepherd, B. (2011). Trade Facilitation and Export Diversification. The World Economy, 34(1), 101-122.

Djankov, S., Freund, C., and Pham, C., (2010). Trading on Time. Review of Economics and Statistics, 92(1), 166-173.

Djimeu, E.W., and Omgba, L.D. (2019). Oil windfalls and export diversification in oil-producing countries: Evidence from oil booms. Energy Economics, 78, 494507.

Donaubauer, J., Meyer, B., and Nunnenkamp, P. (2016). Aid, Infrastructure and FDI: Assessing the Transmission Channel with a New Index of Infrastructure. World Development, 78, 230-245.

Dreher, A., Nunnenkamp, P., and Thiele, R. (2008). Does Aid for Education Educate Children? Evidence from Panel Data. World Bank Economic Review, 22(2), 291-314.

Eichengreen, B., and Gupta, P. (2013). The Real Exchange Rate and Export Growth Are Services Different? World Bank Policy Research Working Paper 6629, World Bank, Washington, D.C.

Föllmi, R., Fuest, A., an de Meulen, P., Micheli, M., Schmidt, T., and Zwick, L. (2018). Openness and productivity of the Swiss economy. Swiss Journal of Economics and Statistics, 154, Article number: 17 (2018).

Francois, J., and Manchin, M. (2013). Institutions, infrastructure and trade. World Development, 46, 165-175.

Freund, C., and Weinhold, D. (2002). The Internet and international trade in services. American Economic Review, 92, $236-240$.

Freund, C., and Weinhold, D. (2004) The effect of the Internet on international trade. Journal of International Economics, 62(1), 171-189.

Giri, R., Quayyum, S., and Yin, R. (2019). Understanding Export Diversification: Key Drivers and Policy Implications. IMF Working Paper N WP/19/105, International Monetary Fund, Washington, D.C.

Gnangnon, S. K. (2018). Aid for trade and trade policy in recipient countries. The International Trade Journal, 32(5), $439-464$.

Gnangnon, S.K. (2019a). Aid for trade and export diversification in recipient-countries. The World Economy, 42(2), 396-418.

Gnangnon, S.K. (2019b). Does the Impact of Aid for Trade on Export Product Diversification depend on Structural economic policies in Recipient-Countries? Economic Issues, 24(1), 59-87.

Gnangnon, S.K. (2019c). Aid for Trade and Recipient-Countries' Export Structure: Does Trade Policy Liberalization Matter? Arthaniti: Journal of Economic Theory and Practice, 18(1), 56-85.

Gnangnon, S. K. (2020a). Effect of the Internet on Services Export Diversification. Journal of Economic Integration, 35(3), 519-558. 
Gnangnon, S. K. (2020b). Tax Reform, Trade Openness and Export Product Diversification in Developing Countries. CESifo Economic Studies, ifaa011, https://doi.org/10.1093/cesifo/ifaa011

Gnangnon, S.K. (2020c). Aid for Trade and Real Exchange Rate in Recipient-Countries. Research Square Preprint Paper, https://www.researchsquare.com/article/rs-16500/v1

Gnangnon, S.K. (2021). Economic Complexity and Poverty in Developing Countries. Preprints 2021, 2021010602 (doi: 10.20944/preprints202101.0602.v1).

Gnangnon. S.K., and lyer, H. (2018). Does bridging the Internet Access Divide contribute to enhancing countries' integration into the global trade in services markets? Telecommunications Policy, 42(1), 61-77.

Görg, H., and Greenaway, D. (2004). Much ado about nothing? Do domestic firms really benefit from foreign direct investment?. World Bank Research Observer, 19(2), 171-197.

Görg, H., and Srobl, E. (2001). Multinational companies and productivity spillovers: a meta-analysis. Economic Journal, 111 (475), F723-F739.

Gorodnichenko, Y., Svejnar, J., and Terrell, K. (2020). Do foreign investment and trade spur innovation? European Economic Review, $121,103343$.

Grossman, G. M., and Helpman, E. (1989). Product Development and International Trade. The Journal of Political Economy, 97(6), 1261-83.

Grossman, G.M., and Helpman, E. (1991). Innovation and Growth in the Global Economy. MIT Press, Cambridge, MA, London, United Kingdom.

Grossman, GM, \& Helpman, E. (2015). Globalization and growth. American Economic Review, 105(5), 100-104.

Güneri, B., and Yalta, A. Y. (2020). Does economic complexity reduce output volatility in developing countries? Bulletin of Economic Research, https://doi.org/10.1111/boer.12257

Guzman, M., Ocampo, A.J., and Stiglitz, J.E. (2018). Real exchange rate policies for economic development. World Development, 110, 51-62.

Hartmann, D., Guevara, M.R., Jara-Figueroa, C., Aristarán, M., and Hidalgo, C.A. (2017). Linking economic complexity, institutions, and income inequality. World Development, 93, 75-93.

Hausmann, R., Hwang, J., and Rodrik, D. (2007). What you export matters. Journal of Economic Growth, 12, 1-25.

Hausmann, R., and Hidalgo, C.A. (2009). The building blocks of economic complexity. Proceedings of the National Academy of Sciences, 106 (26), $10570-$ 10575.

Hausmann, R., Hidalgo, C.A. (2011). The network structure of economic output. Journal of Economic Growth, 16(4), 309-342.

Hausmann, R., and Hidalgo, C.A. (2014). The atlas of economic complexity: mapping paths to prosperity. MIT Press, Cambridge.

Helble, M. (2014). The Pacific's Connectivity and Its Trade Implications. Asian Development Bank Institute, Working Paper 499, Philippines.

Helble, M., Mann, C.L., and Wilson, J.S. (2012). Aid for Trade Facilitation. Review of World Economics, 148(2), 357-376.

Hidalgo, C.A., Klinger, B., Barabási, A.-L., Hausmann, R. (2007). The product space conditions the development of nations. Science, 317(5837), 482-487.

Hu, D., You, K., and Esiyok, B. (2021). Foreign direct investment among developing markets and its technological impact on host: Evidence from spatial analysis of Chinese investment in Africa. Technological Forecasting and Social Change, 166, 120593.

Hübler, M. and Pothen, F. (2017). Trade-induced productivity gains reduce incentives to impose strategic tariffs. Economic Modelling, 61, 420-431.

Imbs, J. and Wacziarg R. (2003). Stages of Diversification. American Economic Review, 93(1), 63-86.

Javorcik, B. (2004). Does foreign direct investment increase the productivity of domestic firms? In search of spillovers through backward linkages? American Economic Review, 94(3), 605-627.

Jensen, R. (2007). The Digital Provide: Information (Technology), Market Performance, and Welfare in the South Indian Fisheries Sector. The Quarterly Journal of Economics, 122, 879-924.

Kim, Y.R. (2019). Does aid for trade diversify the export structure of recipient countries? The World Economy, 42(9), $2684-2722$.

Kobayashi, Y., Heinrich, T., and Bryant, K.A. (2021). Public support for development aid during the COVID-19 pandemic. World Development, $138,105248$.

Kotsadam, A., Østby, G., Rustad, S.A., Tollefsen, A.F., and Urdal, H. (2018). Development aid and infant mortality: Micro-level evidence from Nigeria. World Development, 105, 59-69.

Krugman, P. (1979). A Model of Innovation, Technology Transfer, and the World Distribution of Income. Journal of Political Economy, 87(2), $253-66$.

Lall, S. (1992). Technological capabilities and industrialization. World Development, 20(2), 165-186.

Page $15 / 25$ 
Lall, S., Weiss, J., and Zhang, J. (2006). The sophistication of exports: a new trade measure. World Development, 34 (2), $222-237$.

Lapatinas, A. (2019). The effect of the Internet on economic sophistication: An empirical analysis. Economics Letters 174, 35-38.

Lapatinas, A., and Litina, A. (2019). Intelligence and economic sophistication. Empirical Economics, 57, 1731-1750.

Le Caous, E., and Huarng, F. (2020). Economic Complexity and the Mediating Effects of Income Inequality: Reaching Sustainable Development in Developing Countries. Sustainability, 12, 2089.

Lee, H.H., and Ries, J. (2016). Aid for Trade and Greenfield Investment. World Development, 84, 206-218.

Lee, K-K., and Vu, T.V. (2020). Economic complexity, human capital and income inequality: a cross-country analysis. The Japanese Economic Review, 71, 695718.

Lewin, M.K. (2020). Beyond business as usual: Aid and financing education in Sub Saharan Africa. International Journal of Educational Development, 78, 102247.

Limao, N., and Venables, A. J. (2001). Infrastructure, geographical disadvantage, transport costs, and trade. World Bank Economic Review, 15(3), 451-79.

Lin, F. (2015). Estimating the effect of the Internet on international trade. The Journal of International Trade \& Economic Development, 24(3), 409-428.

Ly-My, D. and Lee, H.H. (2019). Effects of aid for trade on extensive and intensive margins of greenfield FDI. The World Economy, $42(7), 2120-2143$.

Maggioni, D., Lo Turco, A., and Gallegati, M. (2016). Does product complexity matter for firms' output volatility? Journal of Development Economics, 121, 94109.

Mealy, P., Farmer, D., and Teytelboym, A. (2019). Interpreting economic complexity. Science Advances, 5(1), eaau1705.

Melitz, M. J. (2003). The impact of trade on intra-industry reallocations and aggregate industry productivity. Econometrica, 71(6), 1695-1725.

Miller, S. M., and Upadhyay, M.P. (2000). The effects of openness, trade orientation, and human capital on total factor productivity. Journal of Development Economics, 63(2), 399-423.

Miranda-Pinto, J. (2021). Production network structure, service share, and aggregate volatility. Review of Economic Dynamics, $39,146-173$.

Navas, A. (2015). Trade liberalisation and innovation under sector heterogeneity. Regional Science and Urban Economics, 50, 42-62.

Newman, C., Rand, J., Talbot, T., and Tarp, F. (2015). Technology transfers, foreign investment and productivity spillovers. European Economic Review, 76, 168187.

OECD (2015). Innovation Policies for Inclusive Growth, OECD Publishing, Paris.

Olarreaga, M. (2016). Trade, Infrastructure and Development. Working Paper N¹77, Fondation pour les Études et Recherches sur le Développement International (FERDI).

Osakwe, P.N., Santos-Paulino, A.U., and Dogan, B. (2018). Trade dependence, liberalization, and exports diversification in developing countries. Journal of African Trade, 5, 19-34.

Osnago, A., and Tan, S.W. (2016). Disaggregating the Impact of the Internet on International Trade. The World Bank Policy Research Working Paper $\mathrm{N}^{\circ}$ WPS7785, World Bank, Washington, D.C.

Parteka A., and Tamberi, M. (2013). What determines export diversification in the development process? Empirical assessment. The World Economy, 36(6), 807-826.

Paunov, C. (2013). Innovation and Inclusive Development: A Discussion of the Main Policy Issues. OECD Science, Technology and Industry Working Paper No. 2013/1, OECD Publishing.

Paunov, C., and Rollo, V. (2016). Has the Internet Fostered Inclusive Innovation in the Developing World? World Development, 78, 587-609.

Poncet, S., and Starosta de Waldemar, F. (2013a). Complexité économique et croissance - Une application au cas chinois. Revue économique, 64 (2013/3), 495-503.

Poncet, S., and Starosta de Waldemar, F. (2013b). Export Upgrading and Growth: The Prerequisite of Domestic Embeddedness. World Development, 51, 104118.

Portugal-Perez, A., and Wilson, J. (2009). Why trade facilitation matters to Africa. World Trade Review, 8(3), 379-416.

Portugal-Perez, A., and Wilson, J.S. (2012). Export Performance and Trade Facilitation Reform: Hard and Soft Infrastructure. World Development, 40(7), 12951307. 
Ross, M. L. (2019). What do we know about export diversification in oil-producing countries? The Extractive Industries and Society, 6(3), 792-806.

Sekkat, K. (2016). Exchange rate misalignment and export diversification in developing countries. The Quarterly Review of Economics and Finance, 59, 1-14.

Sekkat, K., and Varoudakis, A. (2000). Exchange rate management and manufactured exports in Sub-Saharan Africa. Journal of Development Economics, 61(1), 237-253.

Sepehrdoust, H., Davarikish, R., and Setarehie, M. (2019). The knowledge-based products and economic complexity in developing countries. Heliyon, 5(12), e02979.

Smeets, R. (2008). Collecting the pieces of the FDI knowledge spillovers puzzle. World Bank Research Observer, 23(2), $107-138$.

Sohn, J.E. (2013). The impact of aid for trade on the cost and time to trade - The case of Latin America and the Caribbean. ECLAC - International Trade Series No. 122, United Nations Publication LC/L.3715, United Nations, Santiago, Chile.

Stojkoski, V., Utkovski, Z., and Kocarev, L. (2016). The Impact of Services on Economic Complexity: Service Sophistication as Route for Economic Growth. PLoS ONE 11(8): e0161633.

Tran, T. A-D., Phi, M.H., and Diaw, D. (2017) Export diversification and real exchange rate in emerging Latin America and Asia: A South-North vs. South-South decomposition. The Journal of International Trade \& Economic Development, 26(6), 649-676.

UNCTAD (2006). The Least Developed Countries Report 2006: Developing Productive Capacities. United Nations publication. Sales No. E.06.II.D.9. New York and Geneva.

UNCTAD (2016). Benchmarking productive capacities in least developed countries. UNCTAD/WEB/ALDC/2015/9 - United Nations Conference on Trade and Development, Geneva, Switzerland.

UNCTAD (2018). The Least Developed Countries Report 2018: Entrepreneurship for Structural Transformation: Beyond Business as Usual. United Nations publication. Sales No. E.18.II.D.6. New York and Geneva.

UNCTAD (2020a). Building and Utilizing Productive Capacities in Africa and the Least-developed Countries - A Holistic and Practical Guide. UNCTAD, Geneva, Switzerland.

UNCTAD (2020b). The Least Developed Countries Report 2020: Productive Capacities for the New Decade. United Nations publication. Sales No. E.21.II.D.2 New York and Geneva.

UNCTAD (2020c). Building and Utilizing Productive Capacities in Africa and the LDCs - A Holistic and Practical Guide. UNCTAD/ALDC/INF/2020/1, Geneva, Switzerland.

Utkovski, Z., Pradier, M. F., Stojkoski, V., Perez-Cruz, F., and Kocarev, L. (2018). Economic complexity unfolded: Interpretable model for the productive structure of economies. PLoS ONE 13(8), e0200822.

Vemuri, V.K., and Siddiqi, S. (2009). Impact of commercialization of the internet on international trade: A panel study using the extended gravity model. The International Trade Journal, 23(4), 458-484.

Vijil, M. and Wagner, L. (2012). Does Aid for Trade Enhance Export Performance? Investigating on the Infrastructure Channel. World Economy 35 (7), 838-868.

Visser, R. (2019). The effect of the internet on the margins of trade. Information Economics and Policy, 46, 41-54.

Wilson, J. S., Mann, C. L., and Otsuki, T. (2003). Trade facilitation and economic development: a new approach to quantifying the impact. World Bank Economic Review, 17(3), 367-89.

Wilson, J.S., Mann, C.L., and Otsuki, T. (2005). Assessing the Benefits of Trade Facilitation: A Global Perspective. The World Economy, 28(6), 841-871. WTO (World Trade Organization). (2005). Ministerial Declaration on Doha Work Programme. Paper presented at the Sixth Session of Trade Ministers Conference, Hong Kong, China, December 13-18.

Zhu, S. and Fu, X. (2013). Drivers of Export Upgrading. World Development, 51, 221-233.

Zhu, S., and Li, R. (2017). Economic complexity, human capital and economic growth: empirical research based on cross-country panel data. Applied Economics, 49(38), 3815-3828.

\section{Tables}

Table 1: Effect of productive capacities on economic complexity over the full sample and AfT Recipients Estimator. Within Fixed Effects 


\begin{tabular}{|c|c|c|}
\hline & Full Sample & AfT Recipients \\
\hline & ECI & ECI \\
\hline & $(1)$ & $(2)$ \\
\hline & $\mathbf{0 . 0 2 5 2 ^ { * * * }}$ & $\mathbf{0 . 0 2 7 0 * * *}$ \\
\hline & $\mathbf{( 0 . 0 0 4 1 3 )}$ & $\mathbf{( 0 . 0 0 7 0 5 )}$ \\
\hline & $\mathbf{0 . 0 1 8 6 * * *}$ & $\mathbf{0 . 0 1 8 0 * * *}$ \\
\hline Pariables & $\mathbf{( 0 . 0 0 7 0 4 )}$ & $\mathbf{( 0 . 0 0 4 5 3 )}$ \\
\hline & $\mathbf{- 0 . 0 7 7 0 * * *}$ & $-\mathbf{0 . 0 7 7 9 * * *}$ \\
\hline Log(NonAfTTOT) & $(\mathbf{0 . 0 2 5 8 )}$ & $\mathbf{( 0 . 0 2 4 3 )}$ \\
\hline & $0.157^{* * *}$ & 0.0649 \\
\hline Log(GDPC) & $(0.0412)$ & $(0.0441)$ \\
\hline & $0.000737 * * *$ & $0.000790^{* * *}$ \\
\hline OPEN & $(0.000198)$ & $(0.000266)$ \\
\hline & $0.00146^{* * *}$ & $0.00193^{*}$ \\
\hline FINDEV & $(0.000417)$ & $(0.00109)$ \\
\hline & $-0.0962^{*}$ & 0.0168 \\
\hline Log(POP) & $(0.0541)$ & $(0.0491)$ \\
\hline & -0.00109 & -0.000966 \\
\hline TERMS & $(0.000694)$ & $(0.000800)$ \\
\hline & 0.280 & -0.752 \\
\hline Constant & $(0.609)$ & $(0.580)$ \\
\hline & $541-126$ & $374-90$ \\
\hline Observations - Countries & 0.1902 & 0.1874 \\
\hline Within R & &
\end{tabular}

Note: ${ }^{*} p$-value $<0.1 ;{ }^{* *} p$-value $<0.05 ; * *$-value $<0.01$. Robust standard errors are in parenthesis. The dummy variable "NoAfTDum" has not been included in the regressions whose results are reported in column [1] of Table 1 because it is time-invariant. .

Table 2: Effect of productive capacities on economic complexity over the full sample

Estimator: Two-Step System GMM

\begin{tabular}{|c|c|c|c|c|c|c|c|c|c|}
\hline & \multicolumn{9}{|c|}{ Dependent variable: ECI } \\
\hline & & HUMCAP & NATURAL & ENERG & TRANSP & ICT & PRIVATE & INST & SCI \\
\hline & $(1)$ & $(2)$ & (3) & $(4)$ & (5) & (6) & $(7)$ & $(8)$ & (9) \\
\hline $\mathrm{ECI}_{\mathrm{t}-1}$ & $0.521 * * *$ & $0.610^{* * *}$ & $0.720^{* * *}$ & $0.627^{* * *}$ & $0.740^{* * *}$ & $0.709 * * *$ & $0.689^{* * *}$ & $0.750^{* * *}$ & $0.565^{* *}$ \\
\hline & $(0.0249)$ & $(0.0254)$ & $(0.0155)$ & $(0.0237)$ & $(0.0214)$ & $(0.0194)$ & $(0.0217)$ & $(0.0197)$ & $\overline{(0.0209}$ \\
\hline PCI & $0.0596^{* * * *}$ & & & & & & & & \\
\hline & $(0.00564)$ & & & & & & & & \\
\hline Log(AfTTOT) & $0.0202^{* * *}$ & $0.0661^{* * *}$ & $0.0567 * * *$ & $0.0330 * * *$ & $0.0514^{* * *}$ & $0.0619 * * *$ & $0.0243^{* * *}$ & $0.0256^{* * *}$ & $0.0442^{*}:$ \\
\hline & $(0.00809)$ & $(0.00799)$ & $(0.00790)$ & $(0.00722)$ & $(0.00662)$ & $(0.00656)$ & $(0.00805)$ & $(0.00855)$ & $\left(0.0097^{\prime}\right.$ \\
\hline COMPON & & $0.0293^{* * * *}$ & $-0.0166^{* * * *}$ & $0.0366^{* * * *}$ & $0.00464 * *$ & $0.0152^{* * * *}$ & $0.0101^{* * * *}$ & $0.00286^{* * *}$ & $0.0521^{*}$ \\
\hline & & $(0.00393)$ & $(0.00227)$ & $(0.00407)$ & $(0.00234)$ & $(0.00448)$ & $(0.00183)$ & $(0.00144)$ & $(0.0046$ \\
\hline Log(NonAfTTOT) & $-0.0904^{* * * *}$ & $-0.136 * * *$ & $-0.0917 * * *$ & $-0.119 * * *$ & $-0.111 * * *$ & $-0.133^{*} * *$ & $-0.113 * * *$ & $-0.0681 * * *$ & $-0.0796^{*}$ \\
\hline & $(0.0150)$ & $(0.0171)$ & $(0.0129)$ & $(0.0139)$ & $(0.0142)$ & $(0.0140)$ & $(0.0174)$ & $(0.0152)$ & $(0.0186$ \\
\hline NoAfTDum & $-1.484^{* * *}$ & $-1.509^{* * *}$ & $-0.596^{* *}$ & $-1.550 * * *$ & $-1.145^{* * *}$ & $-1.487 * * *$ & $-1.652^{* * *}$ & $-0.852^{* * *}$ & $-0.639^{1}$ \\
\hline & $(0.278)$ & $(0.366)$ & $(0.239)$ & $(0.306)$ & $(0.285)$ & $(0.259)$ & $(0.282)$ & $(0.240)$ & $(0.341)$ \\
\hline $\log ($ GDPC) & $-0.0640 * * *$ & $-0.108 * * *$ & 0.0134 & $-0.0725 * * *$ & $0.0323^{*}$ & 0.0236 & $0.0561 * *$ & $0.0598^{* * *}$ & -0.011( \\
\hline & $(0.0218)$ & $(0.0282)$ & $(0.0191)$ & $(0.0229)$ & $(0.0167)$ & $(0.0183)$ & $(0.0229)$ & $(0.0207)$ & $(0.0187$ \\
\hline OPEN & $0.00195^{* * *}$ & $0.000692 *$ & $0.000926^{* * *}$ & $0.00182^{* * *}$ & $0.00130^{* * *}$ & $0.00194^{* * * *}$ & $0.00213^{* * * *}$ & $0.00177^{* * * *}$ & $0.00182^{*}$ \\
\hline & $(0.000347)$ & $(0.000410)$ & $(0.000303)$ & $(0.000290)$ & $(0.000260)$ & $(0.000297)$ & $(0.000289)$ & $(0.000259)$ & $(0.00030$ \\
\hline FINDEV & $-5.98 \mathrm{e}-07$ & 0.000391 & $1.84 \mathrm{e}-05$ & $-2.06 e-05$ & $0.000626^{* *}$ & $0.000705^{* *}$ & -0.000553 & $1.01 \mathrm{e}-05$ & 0.00036 \\
\hline & $(0.000348)$ & $(0.000378)$ & $(0.000279)$ & $(0.000317)$ & $(0.000275)$ & $(0.000295)$ & $(0.000368)$ & $(0.000255)$ & $(0.00023$ \\
\hline$\overline{\log (P O P)}$ & $0.0588^{* * * *}$ & -0.0180 & 0.0167 & $0.0344 * *$ & $0.0290 * *$ & $0.0451^{* * *}$ & $0.0961^{* * *}$ & $0.0721^{* * *}$ & 0.0153 \\
\hline & $(0.0153)$ & $(0.0256)$ & $(0.0193)$ & $(0.0174)$ & $(0.0147)$ & $(0.0145)$ & $(0.0106)$ & $(0.0128)$ & $(0.0128$ \\
\hline TERMS & $-0.00188^{* * * *}$ & $-0.00165^{* * *}$ & $-0.00169^{* * *}$ & $-0.00239 * * *$ & $-0.00176^{* * *}$ & $-0.00192^{* * *}$ & $-0.00158^{* * *}$ & $-0.00184^{* * *}$ & $-0.00107^{\prime}$ \\
\hline & $(0.000207)$ & $(0.000275)$ & $(0.00$ & $(0.000249)$ & $(0.000248)$ & $(0.000233)$ & $(0.000232)$ & $(0.000243)$ & $(0.00029$ \\
\hline Constant & -0.666 & $1.399 * *$ & $1.388^{* * *}$ & $0.953 * *$ & 0.516 & 0.504 & $-1.031 * *$ & $-0.876^{* *}$ & -0.492 \\
\hline & $(0.424)$ & $\begin{array}{l}(0.580) \\
\end{array}$ & $(0.442)$ & $(0.429)$ & $(0.404)$ & $(0.357)$ & $(0.523)$ & $(0.408)$ & $(0.417)$ \\
\hline $\begin{array}{c}\text { Observations - } \\
\text { Countries }\end{array}$ & $541-126$ & $541-126$ & $541-126$ & $541-126$ & $541-126$ & $541-126$ & $541-126$ & $541-126$ & $541-12$ \\
\hline $\begin{array}{l}\text { Number of } \\
\text { Instruments }\end{array}$ & 86 & 86 & 86 & 86 & 86 & 86 & 86 & 86 & 86 \\
\hline AR1 (P- & 0.0156 & 0.0126 & 0.0132 & 0.0156 & 0.0146 & 0.0159 & 45 & 0.0158 & 0.0131 \\
\hline AR2 (P-V & 0.4679 & 0.5351 & 0.4443 & 0.4086 & 0.4330 & 0.4072 & 0.4249 & 0.4697 & 0.5281 \\
\hline Sargan (P-Value & 0.3247 & 0.4021 & 0.4296 & 0.3721 & 0.1733 & 0.1920 & 0.1400 & 0.1358 & 0.251 \\
\hline
\end{tabular}

Note: ${ }^{*} p$-value<0.1; **p-value<0.05; ***p-value<0.01. Robust Standard Errors are in parenthesis. In the two-step system GMM estimations, the variables "PCI" and all its components, "AfTTOT", "NonAfTTOT", "GDPC", "OPEN", "FINDEV" have been considered as endogenous. have been treated as endogenous. Time dummies have been included in the regressions. The variable "COMPON" is a component of the index of overall productive capacities.

Table 3: Effect of productive capacities on economic complexity over the sub-sample of AfT Recipients Estimator. Two-Step System GMM 


\begin{tabular}{|c|c|c|c|c|c|c|c|c|c|}
\hline & \multicolumn{9}{|c|}{ Dependent variable: ECI } \\
\hline & & HUMCAP & NATURAL & ENERG & TRANSP & ICT & PRIVATE & INST & SCI \\
\hline & $(1)$ & $(2)$ & (3) & (4) & (5) & (6) & (7) & (8) & (9) \\
\hline $\mathrm{ECI}_{\mathrm{t}-1}$ & $0.416^{* * *}$ & $0.548 * * *$ & $0.704^{* * *}$ & $0.537 * * *$ & $0.694^{* * *}$ & $0.670^{* * *}$ & $0.690^{*} * *$ & $0.734^{* * *}$ & $0.511^{* *>}$ \\
\hline & $(0.0181)$ & $(0.0280)$ & $(0.0241)$ & $(0.0262)$ & $(0.0247)$ & $(0.0184)$ & $(0.0204)$ & $(0.0205)$ & $(0.0229)$ \\
\hline PCI & $0.0864 * * *$ & & & & & & & & \\
\hline & $(0.00528)$ & & & & & & & & \\
\hline Log(AfTTOT) & $0.0111^{* * *}$ & $0.0448^{* * *}$ & $0.0518^{* * *}$ & $0.0343^{* * * *}$ & $0.0523^{* * *}$ & $0.0510^{* * *}$ & $0.0453^{* * *}$ & $0.0135 * *$ & $0.0563^{* *}$ \\
\hline & $(0.00529)$ & $(0.00750)$ & $(0.00484)$ & $(0.00625)$ & $(0.00508)$ & $(0.00444)$ & $(0.00515)$ & $(0.00537)$ & $(0.00681$ \\
\hline COMPON & & $0.0350 * * *$ & $-0.0195^{* * * *}$ & $0.0513^{* * *}$ & $0.00988^{* * * *}$ & $0.0157 * * *$ & $0.0114 * * *$ & $0.00552^{* * *}$ & $0.0632 * \pi$ \\
\hline & & $(0.00334)$ & $(0.00178)$ & $(0.00413)$ & $(0.00280)$ & $(0.00427)$ & $(0.00163)$ & $(0.000964)$ & $(0.0047 \epsilon$ \\
\hline Log(NonAfTTOT) & $-0.0948 * * *$ & $-0.110^{* * *}$ & $-0.111 * * *$ & $-0.126^{* * *}$ & $-0.124 * * *$ & $-0.138 * * *$ & $-0.136 * * *$ & $-0.0839 * * *$ & $-0.111 * *$ \\
\hline & $(0.0141)$ & $(0.0129)$ & $(0.0101)$ & $(0.0183)$ & $(0.0110)$ & $(0.0120)$ & $(0.00989)$ & $(0.0111)$ & $(0.0127)$ \\
\hline Log (GDPC) & $-0.138^{* * *}$ & $-0.0616^{* * *}$ & 0.0135 & $-0.187^{* * * *}$ & $0.0362^{* *}$ & 0.0112 & $0.103^{* * *}$ & $0.0505^{* * *}$ & -0.0182 \\
\hline & $(0.0247)$ & $(0.0168)$ & $(0.0114)$ & $(0.0286)$ & $(0.0143)$ & $(0.0129)$ & $(0.0201)$ & $(0.0157)$ & $(0.0185)$ \\
\hline OPEN & $0.00197^{* * *}$ & 0.000572 & $0.00204 * * *$ & $0.00298^{* * *} *$ & $0.00218^{* * *}$ & $0.00237^{*} * *$ & $0.00272^{* * * *}$ & $0.00229 * * *$ & $0.00204^{*}:$ \\
\hline & $(0.000472)$ & $(0.000578)$ & $(0.000427)$ & $(0.000639)$ & $(0.000481)$ & $(0.000630)$ & $(0.000515)$ & $(0.000505)$ & $(0.00049$ \\
\hline FINDEV & -0.000348 & 0.000297 & 0.000502 & $0.00249^{* * *}$ & $0.00157^{* * *}$ & $0.00195^{* * *}$ & $-0.000954^{*}$ & 0.000258 & 0.00041 \\
\hline & $(0.000595)$ & $(0.000516)$ & $(0.000557)$ & $(0.000785)$ & $(0.000433)$ & $(0.000429)$ & $(0.000528)$ & $(0.000329)$ & $(0.00058$ \\
\hline$\overline{\mathrm{Log}}(\mathrm{POP})$ & $0.0879^{* * *}$ & $0.0492^{* * *}$ & $0.0532^{* * *}$ & -0.00341 & $0.0600^{* * *}$ & $0.0649 * * *$ & $0.106^{* * *}$ & $0.104^{* * *}$ & $0.0257^{*}$ \\
\hline & $(0.0183)$ & $(0.0162)$ & $(0.0148)$ & $(0.0292)$ & $(0.0130)$ & $(0.0170)$ & $(0.0131)$ & $(0.0130)$ & $(0.0142)$ \\
\hline TERMS & $-0.00193^{* * *}$ & $-0.00191 * * *$ & $-0.00188^{* * *}$ & $-0.00235^{* * *}$ & $-0.00183^{* * *}$ & $-0.00204 * * *$ & $-0.00153^{* * *}$ & $-0.00167^{* * *}$ & $-0.00120 *$ \\
\hline & $(0.000175)$ & $(0.000202)$ & $(0.000233)$ & $(0.000247)$ & $(0.000191)$ & $(0.000195)$ & $(0.000170)$ & $(0.000222)$ & $(0.00026$ \\
\hline Constant & $-1.164^{* * *}$ & -0.463 & $1.338^{* * * *}$ & $1.999^{* * *}$ & 0.00456 & 0.302 & $-1.645^{* * *}$ & $-0.978 * * *$ & -0.435 \\
\hline & $(0.378)$ & $(0.334)$ & $(0.326)$ & $(0.557)$ & $(0.279)$ & $(0.302)$ & $(0.443)$ & $(0.315)$ & $(0.403)$ \\
\hline $\begin{array}{c}\text { Observations - } \\
\text { Countries }\end{array}$ & $374-90$ & $374-90$ & $374-90$ & $374-90$ & $374-90$ & $374-90$ & $374-90$ & $374-90$ & $374-90$ \\
\hline $\begin{array}{l}\text { Number of } \\
\text { Instruments }\end{array}$ & 76 & 76 & 76 & 76 & 76 & 76 & 76 & 76 & 76 \\
\hline AR1 (P-Value) & 0.0210 & 0.0159 & 0.0191 & 0.0238 & 0.0195 & 0.0179 & 0.0186 & 0.0185 & 0.0166 \\
\hline AR2 (P-Value) & 0.4804 & 0.4946 & 0.3399 & 0.3233 & 0.3527 & 0.3468 & 0.3320 & 0.3668 & 0.3555 \\
\hline Sargan (P-Value) & 0.5009 & 0.4529 & 0.6391 & 0.8089 & 0.3731 & 0.1700 & 0.2255 & 0.2432 & 0.3624 \\
\hline
\end{tabular}

Table 4: Effect of productive capacities on economic complexity over sub-samples of old industrialized countries and LDCs Estimator: Two-Step System GMM 


\begin{tabular}{|c|c|c|c|c|c|c|c|c|c|}
\hline & & & & & Dependent & ariable: ECI & & & \\
\hline Variables & & HUMCAP & NATURAL & ENERG & TRANSP & ICT & PRIVATE & INST & \\
\hline & $(1)$ & $(2)$ & (3) & $(4)$ & (5) & (6) & $(7)$ & $(8)$ & \\
\hline $\mathrm{ECI}_{\mathrm{t}-1}$ & $0.594^{* * *}$ & $0.596 * * *$ & $0.749 * * *$ & $0.575^{* * *}$ & $0.745^{* * *}$ & $0.667^{* * *}$ & $0.598 * * *$ & $0.639 * * *$ & 0.5 \\
\hline & $(0.0174)$ & $(0.0297)$ & $(0.0205)$ & $(0.0241)$ & $(0.0213)$ & $(0.0219)$ & $(0.0230)$ & $(0.0201)$ & $(0$. \\
\hline PCI & $0.0466^{* * * *}$ & & & & & & & & \\
\hline & $(0.00355)$ & & & & & & & & \\
\hline PCI*OLDIND & $0.0184 *$ & & & & & & & & \\
\hline & $(0.00949)$ & & & & & & & & \\
\hline PCI*LDC & $-0.0351^{* * * *}$ & & & & & & & & \\
\hline & $(0.00793)$ & & & & & & & & \\
\hline Log(AfTTOT) & $0.0260 * * *$ & $0.0901 * * *$ & $0.0418^{* * *}$ & $0.0515^{* * *}$ & $0.0564 * * *$ & $0.0723^{* * *}$ & $0.0621^{* * *}$ & $0.0306^{* * *}$ & 0.0 \\
\hline & $(0.00655)$ & $(0.00862)$ & $(0.0132)$ & $(0.00827)$ & $(0.00809)$ & $(0.00557)$ & $(0.00759)$ & $(0.00827)$ & $(0.1$ \\
\hline$\left[\log \left(\right.\right.$ AfTTOT) ${ }^{*} \mathrm{LDC}$ & $0.101 * * *$ & & & & & & & & \\
\hline & $(0.0221)$ & & & & & & & & \\
\hline COMPON & & $0.0217 * * *$ & $-0.00988^{* * * *}$ & $0.0366 * * *$ & -0.00169 & $0.0103^{* *}$ & $0.0152^{* * * *}$ & $0.00446^{* * * *}$ & 0.0 \\
\hline & & $(0.00390)$ & $(0.00346)$ & $(0.00772)$ & $(0.00340)$ & $(0.00405)$ & $(0.00217)$ & $(0.00130)$ & $(0.1$ \\
\hline COMPON*OLDIND & & $0.0135^{* * *}$ & -0.00717 & 0.00770 & -0.000676 & $0.0149^{* * * *}$ & $0.0204 * *$ & -0.000521 & -0.1 \\
\hline & & $(0.00604)$ & $(0.00886)$ & $(0.0175)$ & $(0.00492)$ & $(0.00510)$ & $(0.00963)$ & $(0.00362)$ & 0.1 \\
\hline COMPON*LDC & & $0.00605^{*}$ & $-0.0171 * * *$ & -0.0175 & $0.0281 * * *$ & $0.0296 * * *$ & $-0.00492 *$ & $0.00571 * *$ & -0.0 \\
\hline & & $(0.00367)$ & $(0.00522)$ & $(0.0120)$ & $(0.00691)$ & $(0.00774)$ & $(0.00280)$ & $(0.00279)$ & $(0.1$ \\
\hline PCI*HIC & & & & & & & & & \\
\hline & & & & & & & & & \\
\hline OLDIND & $-0.757 *$ & $-0.892^{* *}$ & 0.541 & 0.0277 & 0.213 & $-0.230^{* *}$ & $-1.583^{*}$ & -0.105 & \\
\hline & $(0.402)$ & $(0.403)$ & $(0.458)$ & $(0.582)$ & $(0.140)$ & $(0.110)$ & $(0.835)$ & $(0.283)$ & $(0$ \\
\hline LDC & $-1.300^{* * *}$ & $-0.461^{* * *}$ & $0.671^{* *}$ & 0.0158 & $-0.783^{* * *}$ & $-0.425^{* * *}$ & -0.110 & $-0.692^{* * *}$ & 0.4 \\
\hline & $(0.271)$ & $(0.148)$ & $(0.327)$ & $(0.245)$ & $(0.123)$ & $(0.0557)$ & $(0.199)$ & $(0.114)$ & $(0$. \\
\hline HIC & & & & & & & & & \\
\hline & & & & & & & & & \\
\hline Log(NonAfTTOT) & $-0.119 * * *$ & $-0.159 * * *$ & $-0.0987 * * *$ & $-0.143^{* * *}$ & $-0.173^{* * *}$ & $-0.180^{* * *}$ & $-0.183^{* * *}$ & $-0.0927 * * *$ & -0 \\
\hline & $(0.0108)$ & $(0.0178)$ & $(0.0237)$ & $(0.0127)$ & $(0.0108)$ & $(0.0162)$ & $(0.0165)$ & $(0.0142)$ & $(0$. \\
\hline NoAfTDum & $-1.760 * * *$ & $-1.372 * * *$ & $-0.997 * *$ & $-1.703^{* * *} *$ & $-2.075^{* * *}$ & $-1.932 * * *$ & $-2.153^{* * * *}$ & $-0.985 * * *$ & -0 \\
\hline & $(0.189)$ & $(0.391)$ & $(0.425)$ & $(0.288)$ & $(0.255)$ & $(0.335)$ & $(0.337)$ & $(0.250)$ & $(0$ \\
\hline $\log (G D P C)$ & $-0.149 * * *$ & $-0.138 * * *$ & $-0.102^{* * *}$ & $-0.158^{* * *}$ & $-0.154^{* * *}$ & $-0.101^{* * * *}$ & $-0.0823^{* * *}$ & -0.00979 & -0 \\
\hline & $(0.0173)$ & $(0.0289)$ & $(0.0300)$ & $(0.0323)$ & $(0.0258)$ & $(0.0253)$ & $(0.0300)$ & $(0.0248)$ & $(0$. \\
\hline OPEN & $0.000862^{* * *}$ & $0.000842^{* * *}$ & $0.00148^{* * *}$ & $0.00282^{* * *}$ & $0.00184^{* * *}$ & $0.00178^{* * *}$ & $0.00222^{* * *}$ & $0.00179^{* * *}$ & 0.00 \\
\hline & $(0.000215)$ & $(0.000324)$ & $(0.000488)$ & $(0.000450)$ & $(0.000267)$ & $(0.000336)$ & $(0.000348)$ & $(0.000402)$ & $(0.0$ \\
\hline FINDEV & $0.000515^{* *}$ & 0.000568 & 0.000316 & $0.000880^{* * *}$ & 0.000401 & $0.000829^{* * *}$ & $-0.00100 * * *$ & -0.000270 & 0.0 \\
\hline & $(0.000248)$ & $(0.000348)$ & $(0.000309)$ & $(0.000316)$ & $(0.000260)$ & $(0.000278)$ & \begin{tabular}{|l}
$(0.000372)$ \\
\end{tabular} & $(0.000197)$ & $(0.0$ \\
\hline Log(POP) & $0.0339 * * *$ & -0.00541 & 0.0277 & $0.0505^{* *}$ & $0.0920^{* * *}$ & $0.0644^{* * *}$ & $0.111^{* * *}$ & $0.109 * * *$ & 0. \\
\hline & $(0.0102)$ & $(0.0220)$ & $(0.0190)$ & $(0.0208)$ & $(0.0136)$ & $(0.0128)$ & $(0.0139)$ & $(0.0139)$ & $(0$. \\
\hline TERMS & $-0.00193^{* * *}$ & $-0.00201^{* * *}$ & $-0.00142^{* * *}$ & $-0.00217^{* * *}$ & $-0.00163^{* * *}$ & $-0.00197 * * *$ & $-0.00182^{* * *}$ & $-0.00195^{* * *}$ & -0.00 \\
\hline & $(0.000144)$ & $(0.000225)$ & $(0.000331)$ & $(0.000203)$ & $(0.000202)$ & $(0.000236)$ & $(0.000234)$ & $(0.000184)$ & $(0.0$ \\
\hline Constant & $1.206^{* * *}$ & $1.860^{* * *}$ & $2.190^{* * *}$ & $1.383^{* *}$ & $2.253^{* * *}$ & $2.015^{* * *}$ & 0.254 & -0.534 & -0 \\
\hline & $(0.338)$ & $(0.544)$ & $(0.545)$ & $(0.560)$ & $(0.381)$ & $(0.434)$ & $(0.524)$ & $(0.359)$ & $(0$ \\
\hline Observations - & $541-126$ & $541-126$ & $541-126$ & $541-126$ & $541-126$ & $541-126$ & $541-126$ & $541-126$ & 54: \\
\hline $\begin{array}{l}\text { Number of } \\
\text { Instruments }\end{array}$ & 107 & 98 & 77 & 98 & 98 & 98 & 98 & 98 & \\
\hline AR1 (P-Value) & 0.0157 & 0.0105 & 0.0141 & 0.0139 & 0.0116 & 0.0125 & 0.0116 & 0.0149 & $\overline{0}$. \\
\hline AR2 (P-Value) & 0.4666 & 0.5412 & 0.4529 & 0.4619 & 0.4873 & 0.4573 & 0.4334 & 0.4731 & 0 . \\
\hline Sargan (P-Value) & 0.3167 & 0.1993 & 0.2672 & 0.6716 & 0.1711 & 0.4698 & 0.4408 & 0.1846 & 0 . \\
\hline
\end{tabular}

Note: ${ }^{*} p$-value $<0.1 ;{ }^{* *} p$-value $<0.05 ;{ }^{* * *}$-value $<0.01$. Robust Standard Errors are in parenthesis. In the two-step system GMM estimations, the variables "PCI" and all its components, "AfTTOT", "NonAfTTOT", "GDPC", "OPEN", "FINDEV", and the interaction variables have been considered as endogenous. have been treated as endogenous. Time dummies have been included in the regressions. The variable "COMPON" is a component of the index of overall productive capacities.

Table 5: Effect of productive capacities on export product diversification, and export product quality, all of these being key aspects of economic complexity, over the full sample and the sub-sample of AfT Recipients

Estimator. Two-Step System GMM 


\begin{tabular}{|c|c|c|c|c|c|c|}
\hline \multirow[b]{2}{*}{ Variables } & \multicolumn{3}{|c|}{ Full Sample } & \multicolumn{3}{|c|}{ AfT Recipients } \\
\hline & EPCUNCT & EPCIMF & QUALIMF & EPCUNCT & EPCIMF & QUALIMF \\
\hline & $(1)$ & $(2)$ & $(3)$ & $(4)$ & (5) & $(6)$ \\
\hline One-Period Lag of the dependent Variable & $0.725^{* * *}$ & $0.926^{* * *}$ & $0.764 * * *$ & $0.688^{* * *}$ & $0.858 * * *$ & $0.715^{* * *}$ \\
\hline & $(0.0211)$ & $(0.0263)$ & $(0.0233)$ & $(0.0123)$ & $(0.0162)$ & $(0.0186)$ \\
\hline PCI & $-0.0145^{* * * *}$ & $-0.0438 * * *$ & $0.00332 * *$ & $-0.0127 * * *$ & $-0.0212 * * *$ & $0.00731 * * *$ \\
\hline & $(0.00148)$ & $(0.0104)$ & $(0.00130)$ & $(0.000739)$ & $(0.00689)$ & $(0.00142)$ \\
\hline$\overline{\log (\mathrm{AfTTOT})}$ & $-0.00467^{*}$ & $-0.0334 * *$ & $0.00387 * *$ & $-0.00515^{* *}$ & $-0.0653^{* * * *}$ & 0.000561 \\
\hline & $(0.00266)$ & $(0.0149)$ & $(0.00159)$ & $(0.00218)$ & $(0.00602)$ & $(0.00163)$ \\
\hline Log(NonAfTTOT) & 0.00567 & -0.0229 & 0.00231 & $0.00484^{* * *}$ & $0.107^{* * * * *}$ & 0.000241 \\
\hline & $(0.00428)$ & $(0.0204)$ & $(0.00262)$ & $(0.00218)$ & $(0.00719)$ & $(0.00295)$ \\
\hline NoAfTDum & 0.0906 & $-0.758 *$ & $0.0891^{* *}$ & & & \\
\hline & $(0.0720)$ & $(0.400)$ & $(0.0431)$ & & & \\
\hline Log(GDPC) & $0.114^{* * *}$ & $0.621^{* * *}$ & $0.0134^{* * *}$ & $0.0709^{* *}$ & $-0.872^{* * *}$ & -0.00545 \\
\hline & $(0.0327)$ & $(0.206)$ & $(0.00474)$ & $(0.0287)$ & $(0.237)$ & $(0.00453)$ \\
\hline$[\log (\mathrm{GDPC})]^{2}$ & $-0.00430^{* *}$ & $-0.0300^{* *}$ & & -0.00150 & $0.0630^{* * *}$ & \\
\hline & $(0.00215)$ & $(0.0130)$ & & $(0.00185)$ & $(0.0151)$ & \\
\hline OPEN & $0.000313^{* * *}$ & $0.00112^{* * *}$ & $-3.64 e-05$ & $0.000430^{* * *}$ & $0.00157 * * *$ & $7.96 \mathrm{e}-06$ \\
\hline & $(5.78 \mathrm{e}-05)$ & $(0.000348)$ & $(4.88 \mathrm{e}-05)$ & $(5.12 \mathrm{e}-05)$ & $(0.000235)$ & $(5.06 \mathrm{e}-05)$ \\
\hline FINDEV & $0.000205^{* * *}$ & $0.000867 *$ & $-5.48 \mathrm{e}-05$ & $-0.000248^{* *}$ & -0.000513 & $-0.000147^{* *}$ \\
\hline & $(7.37 \mathrm{e}-05)$ & $(0.000449)$ & $(6.35 \mathrm{e}-05)$ & $(0.000112)$ & $(0.000696)$ & $(6.72 \mathrm{e}-05)$ \\
\hline $\log (\mathrm{POP})$ & $0.0164^{* * *}$ & $0.139^{* * *}$ & $-0.0126^{* * *}$ & $0.0268^{* * *}$ & $0.0892 * * *$ & $-0.00718^{* * *}$ \\
\hline & $(0.00390)$ & $(0.0213)$ & $(0.00267)$ & $(0.00257)$ & $(0.00852)$ & $(0.00260)$ \\
\hline TERMS & $0.000461^{* * *}$ & $-0.00145^{* * *}$ & $-0.000227^{* * * *}$ & $0.000545^{* * *}$ & -0.000253 & $-0.000281^{* * *}$ \\
\hline & $(6.37 \mathrm{e}-05)$ & $(0.000320)$ & $(4.29 \mathrm{e}-05)$ & $(3.21 \mathrm{e}-05)$ & $(0.000224)$ & $(3.42 \mathrm{e}-05)$ \\
\hline Constant & $-0.551 * * *$ & $-2.842^{* * *}$ & $0.121 * *$ & $-0.563 * * *$ & $1.451^{*}$ & $0.220^{* * *}$ \\
\hline & $(0.112)$ & $(0.922)$ & $(0.0568)$ & $(0.107)$ & $(0.802)$ & $(0.0553)$ \\
\hline Observations - Countries & $575-126$ & $458-126$ & $451-124$ & $407-90$ & $324-90$ & $317-88$ \\
\hline Number of Instruments & 86 & 86 & 61 & 86 & 86 & 61 \\
\hline AR1 (P-Value) & 0.0001 & 0.0020 & 0.0311 & 0.0007 & 0.0029 & 0.0423 \\
\hline AR2 (P-Value) & 0.2766 & 0.6065 & 0.9315 & 0.3634 & 0.4924 & 0.9602 \\
\hline Sargan (P-Value) & 0.1429 & 0.0935 & 0.3159 & 0.4186 & 0.3969 & 0.5006 \\
\hline
\end{tabular}

Note: ${ }^{*} p$-value $<0.1 ;{ }^{* *} p$-value<0.05; ${ }^{* * *}$-value<0.01. Robust Standard Errors are in parenthesis. In the two-step system GMM estimations, the variables "PCI", "AfTTOT", "NonAfTTOT", "GDPC", "OPEN", "FINDEV", and the interaction variables have been considered as endogenous. have been treated as endogenous. Time dummies have been included in the regressions.

Table 6: Interaction effect between productive capacities, AfT flows and NonAfT flows on economic complexity Estimator. Two-Step System GMM

\begin{tabular}{|c|c|}
\hline Variables & ECI \\
\hline & (1) \\
\hline $\mathrm{ECI}_{\mathrm{t}-1}$ & $0.495^{* * *}$ \\
\hline & $(0.0157)$ \\
\hline PCI & $-0.0910 * * *$ \\
\hline & $(0.0211)$ \\
\hline PCI*[Log(AfTTOT) $]$ & $-0.00255^{* * * *}$ \\
\hline & $(0.000620)$ \\
\hline PCI*[Log(NonAfTTOT)] & $0.0104 * * *$ \\
\hline & $(0.00108)$ \\
\hline Log(AfTTOT) & $0.0838^{* * * *}$ \\
\hline & $(0.0155)$ \\
\hline Log(NonAfTTOT) & $-0.385^{* * *}$ \\
\hline & $(0.0304)$ \\
\hline OPEN & $0.00123^{* * *}$ \\
\hline & $(0.000221)$ \\
\hline FINDEV & $-0.000874^{* *}$ \\
\hline & $(0.000401)$ \\
\hline $\log (\mathrm{POP})$ & $0.0769 * * *$ \\
\hline & $(0.0114)$ \\
\hline Log(GDPC) & $-0.0980^{* * *}$ \\
\hline & $(0.0145)$ \\
\hline TERMS & $-0.00192^{* * *}$ \\
\hline & $(0.000113)$ \\
\hline Constant & $3.732^{* * *}$ \\
\hline & $(0.711)$ \\
\hline Observations - Countries & 37490 \\
\hline Number of Instruments & 96 \\
\hline AR1 (P-Value) & 0.0157 \\
\hline AR2 (P-Value) & 0.5173 \\
\hline Sargan (P-Value) & 0.6449 \\
\hline
\end{tabular}

Note: ${ }^{*} p$-value $<0.1 ;{ }^{* *}$-value<0.05; ***p-value<0.01. Robust Standard Errors are in parenthesis. In the two-step system GMM estimations, the variables "PCI", "AfTTOT", "NonAfTTOT", "GDPC", "OPEN", "FINDEV", and the interaction variables have been considered as endogenous. have been treated as endogenous. Time dummies have been included in the regressions.

\section{Figures}




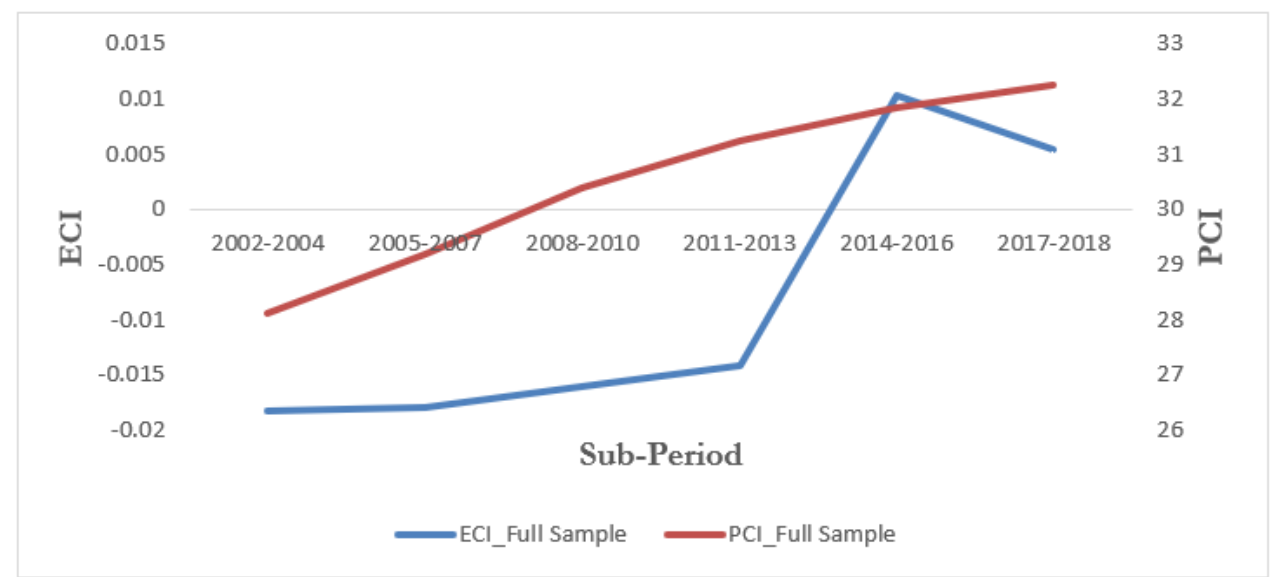

Source: Autbor

\section{Figure 1}

Developments of productive capacity and economic complexity over the full sample

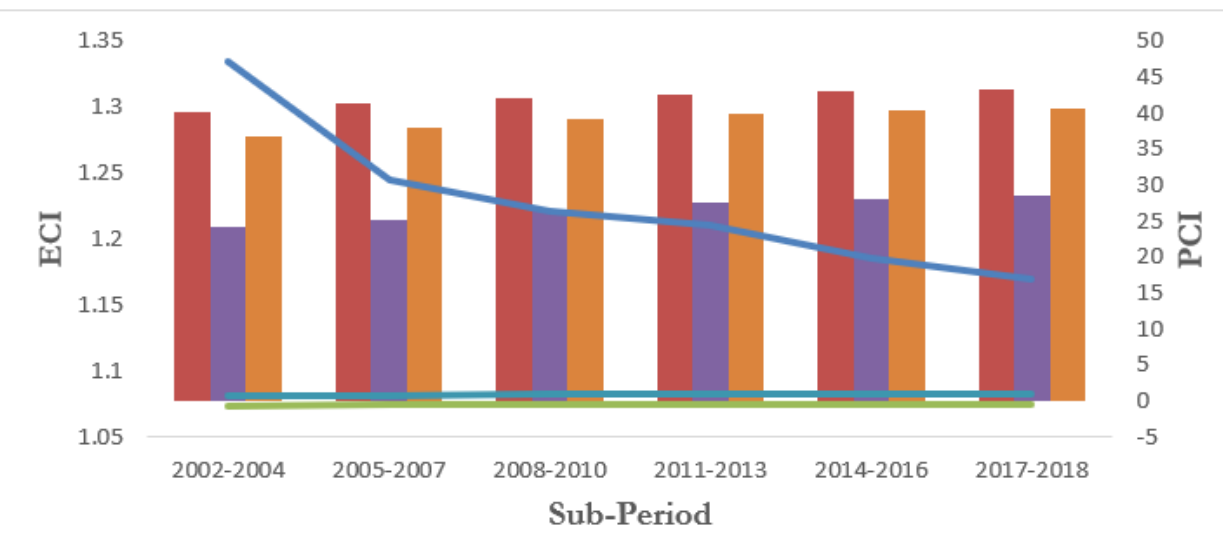

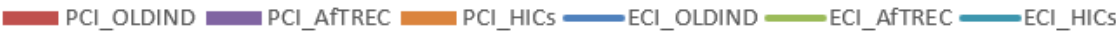

Source: Autbor

\section{Figure 2}

Developments of productive capacity and economic complexity over the sub-samples of old industrialized countries, HICs and AfT Recipients

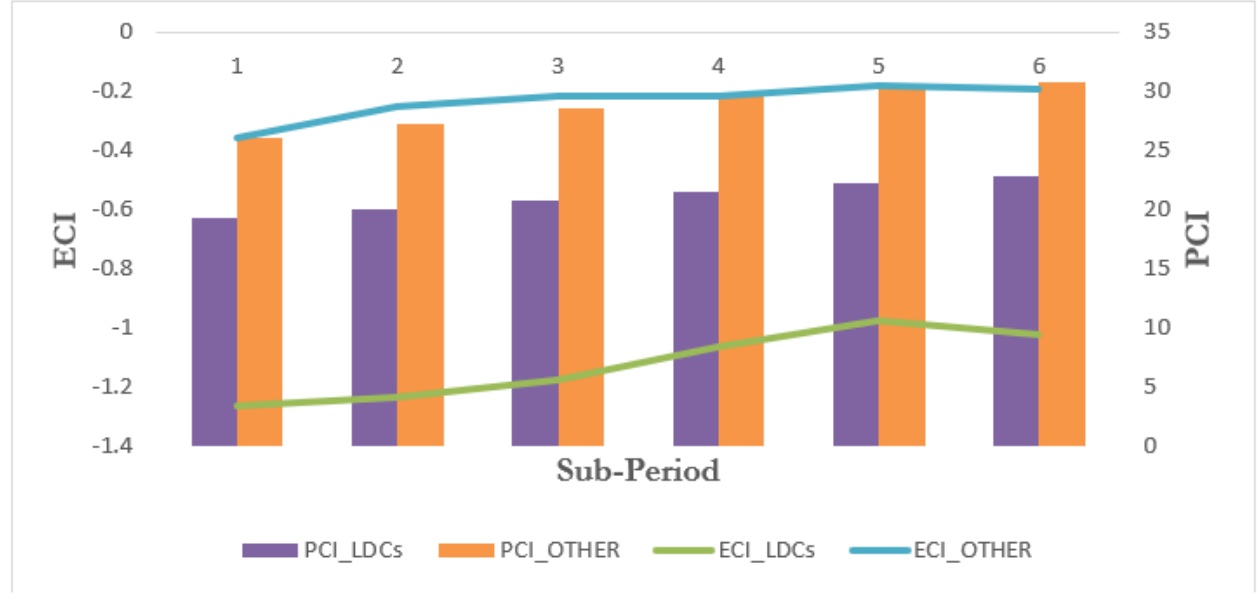

Source: Autbor

Notes: The sub-sample "OTHER" contains NonLDCs among AfT Recipient-Countries.

Figure 3

Page $22 / 25$ 
Developments of productive capacity and economic complexity over the sub-samples of LDCs and the group of "OTHER" countries

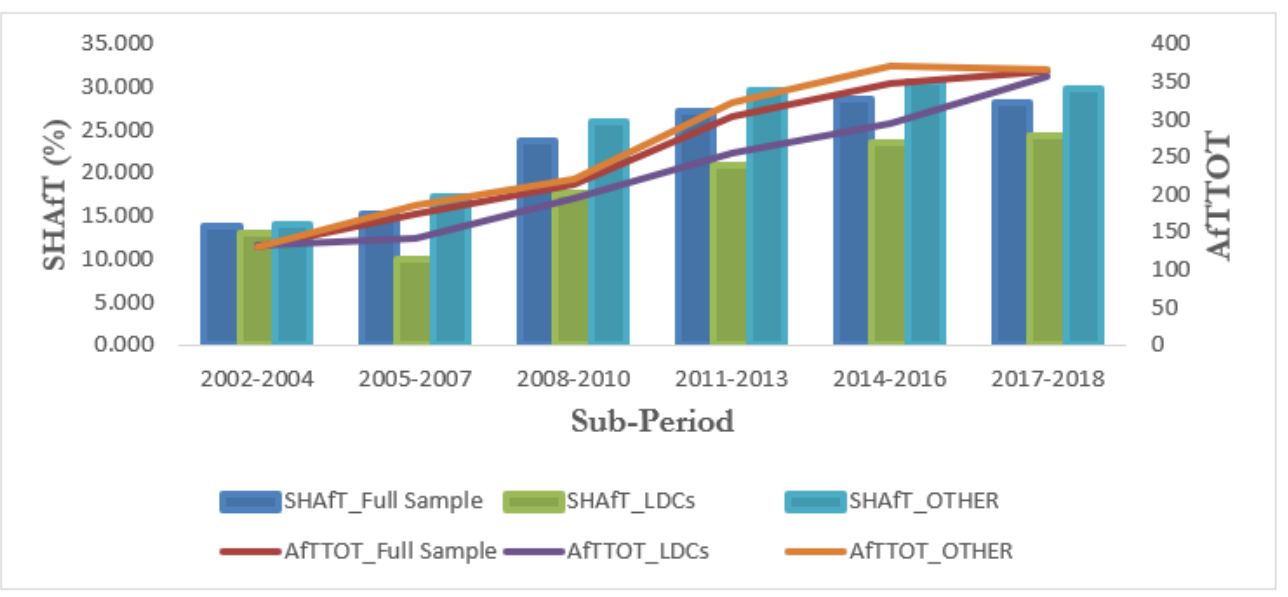

Source: Autbor

Note: "AfTTOT" represents the total AfT flows, and is expressed in million USS, Constant 2018

Prices."SHAfT" represents the share (\%) of total AfT flows in the total gross disbursements ODA flows (both expressed in constant 2018 prices). The sub-sample "OTHER" contains NonLDCs among AfT Recipient-

Countries.

\section{Figure 4}

Developments of total AfT inflows and the share of total AfT flows in total gross ODA flows, over the sample of AfT Recipients, as well as the sub-samples of LDCs and NonLDCs
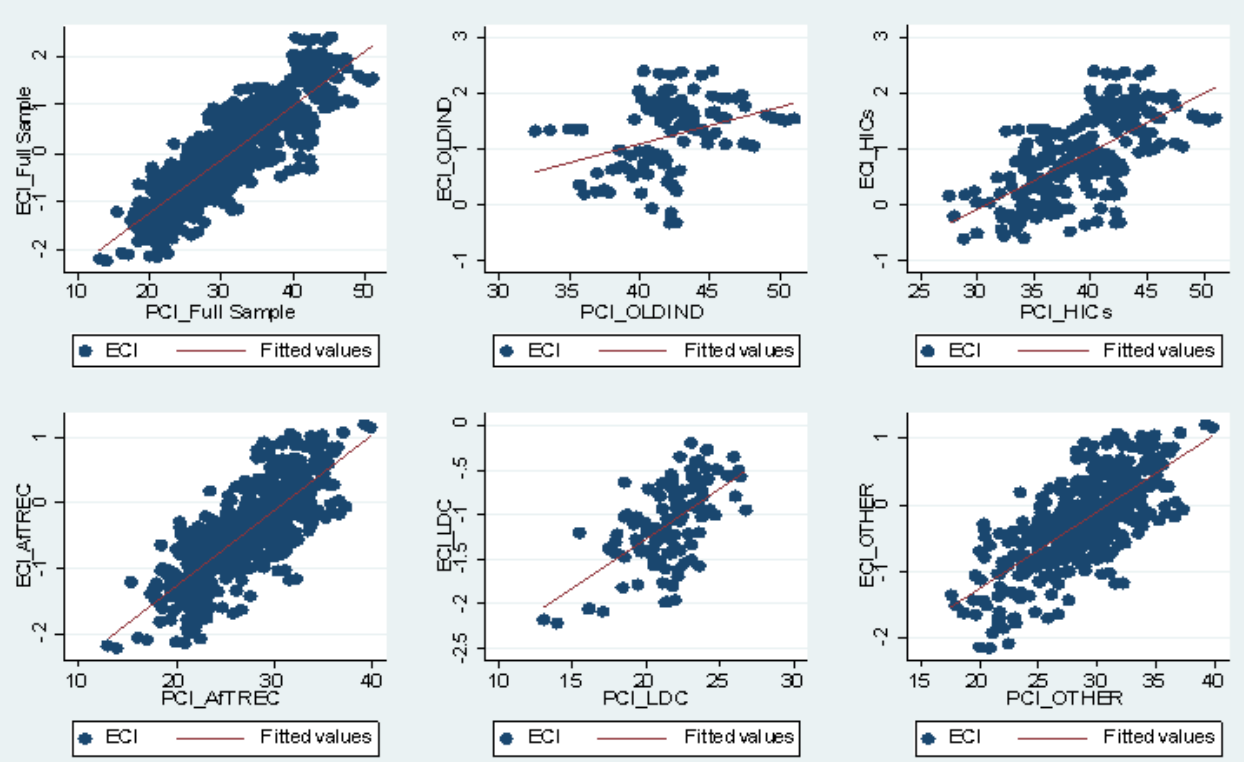

Source: Autbor

\section{Figure 5}

Cross plot between productive capacity and economic complexity over the full sample and the sub-samples of old industrialized countries, HICs, AfTREC, LDCs and OTHER 

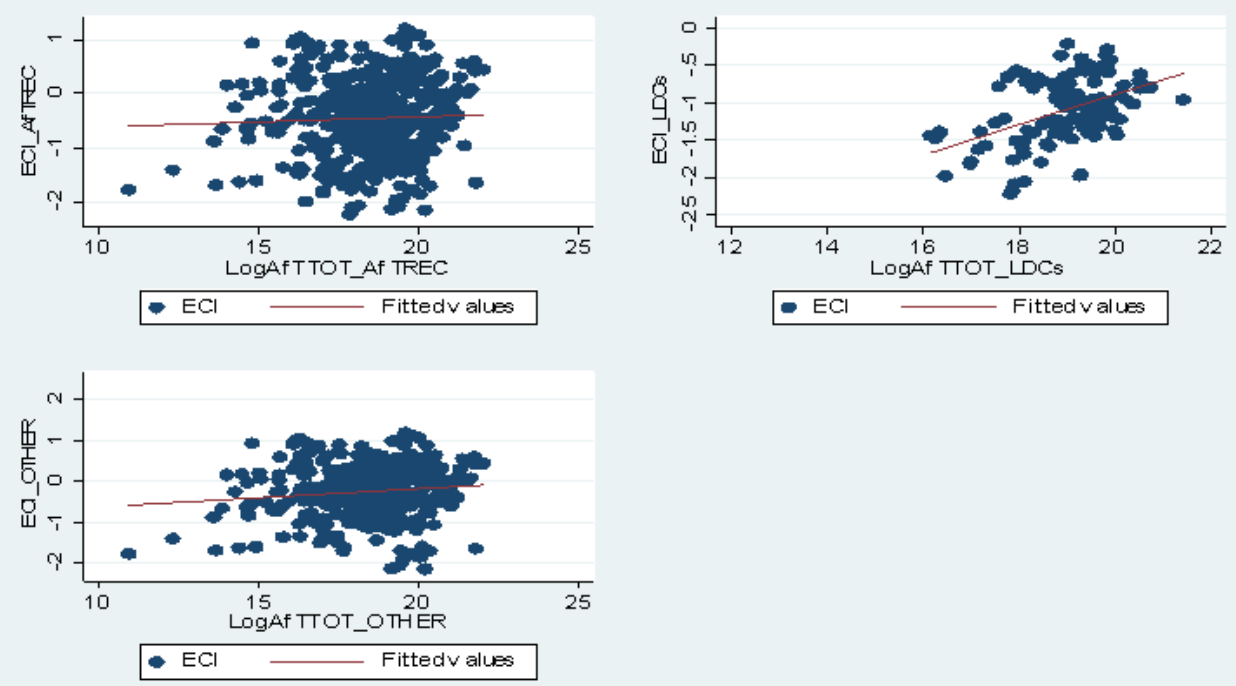

Source: Autbor

Note: The sub-sample "OTHER" contains NonLDCs among AfT Recipient-Countries.

Figure 6

Cross plot between total AfT flows and economic complexity over the sample of AfT Recipients, LDCs and OTHER

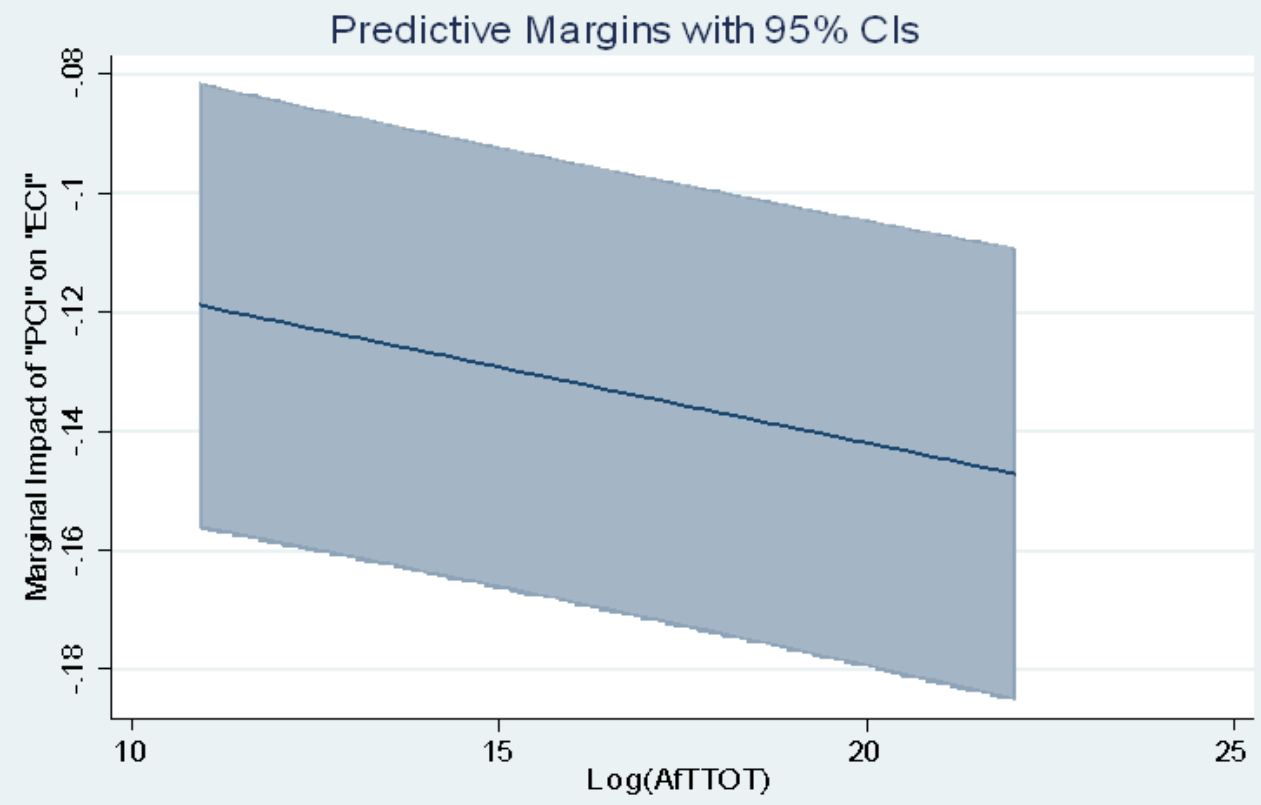

Source: Autbor

Figure 7

Marginal Impact of "PCl" on "ECl", for varying amounts of total AfT 


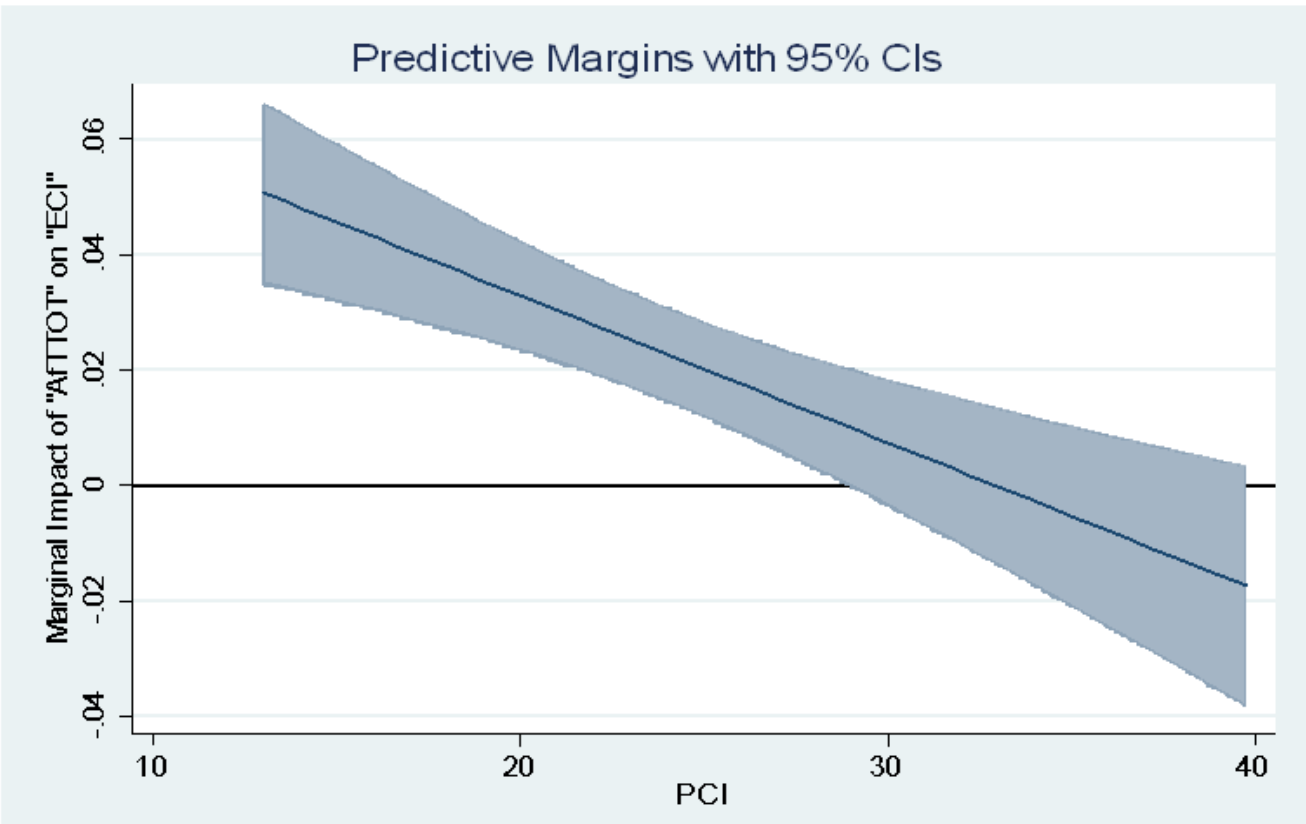

Source: Author

Figure 8

Marginal Impact of "AfTTOT" on "ECl", for varying levels of productive capacities

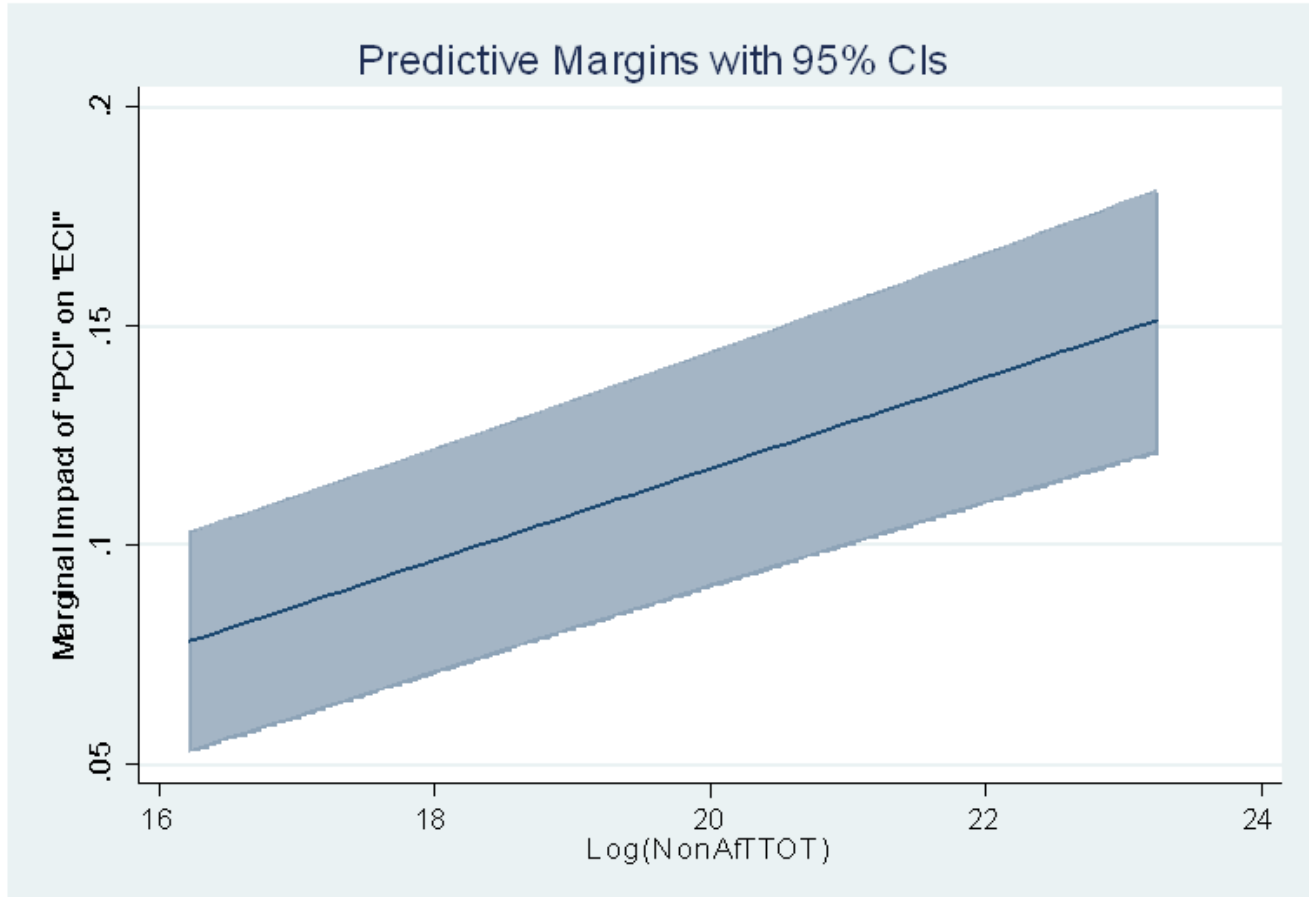

Source: Autbor

Figure 9

Marginal Impact of "PCl" on "ECl", for varying amounts of Total NonAfT flows

\section{Supplementary Files}

This is a list of supplementary files associated with this preprint. Click to download.

- Appendices.docx 